\title{
Cerebrovascular development: mechanisms and experimental approaches
}

\author{
Timothy J. A. Chico ${ }^{1,2,3}$ (D) Elisabeth C. Kugler ${ }^{1,2,3}$ (1)
}

Received: 22 June 2020 / Revised: 4 February 2021 / Accepted: 12 February 2021 / Published online: 10 March 2021

(c) The Author(s) 2021

\begin{abstract}
The cerebral vasculature plays a central role in human health and disease and possesses several unique anatomic, functional and molecular characteristics. Despite their importance, the mechanisms that determine cerebrovascular development are less well studied than other vascular territories. This is in part due to limitations of existing models and techniques for visualisation and manipulation of the cerebral vasculature. In this review we summarise the experimental approaches used to study the cerebral vessels and the mechanisms that contribute to their development.
\end{abstract}

Keywords Brain $\cdot$ Endothelial cells $\cdot$ Immune cells $\cdot$ Lymphatics $\cdot$ Mural cells $\cdot$ Vasculature

\section{Introduction}

The endothelial cells (ECs) of different vascular territories possess distinct molecular and function identities [1-4]. The cerebral ECs are of particular clinical relevance due to their roles in human diseases including stroke, cerebrovascular malformations and vascular dementia [5, 6]. In addition, neurological diseases including neurodegeneration and Alzheimer's disease share risk factors with other vascular diseases and are increasingly believed to have vascular components [7, 8]. Cerebrovascular diseases together incur substantial morbidity and mortality, claiming eighteen million lives annually and consuming $8-21 \%$ of total healthcare expenditure, impacts which are increasing due to an ageing population [5, 6, 9-12]. In this review, we discuss the

Timothy J. A. Chico

t.j.chico@sheffield.ac.uk

$\square$ Elisabeth C. Kugler kugler.elisabeth@gmail.com

https://www.elisabethkugler.com/

1 Department of Infection, Immunity and Cardiovascular Disease, Medical School, University of Sheffield, Beech Hill Road, Sheffield S10 2RX, UK

2 The Bateson Centre, Firth Court, University of Sheffield, Western Bank, Sheffield S10 2TN, UK

3 Insigneo Institute for in Silico Medicine, The Pam Liversidge Building, Sheffield S1 3JD, UK current understanding of cerebrovascular determination and development.

\section{Models and tools for studying cerebrovascular development}

Much of our understanding of the molecular and cellular mechanisms of EC biology comes from in vitro studies. There are arrays of such models from simple monolayers to more complex environments including matrix assays, $3 \mathrm{D}$ gels, and organ cultures (reviewed in [13, 14]). These allow examination of the effect of candidate molecules and mechanisms on in vitro cell behaviours; and to attempt to reproduce the in vivo milieu there have been significant technological advancements in three-dimensional and complex microenvironments. This is exemplified by microfluidic platforms mimicking the cerebral environment and cerebrovascular properties, such as neurovascular interactions [15], and the blood-brain-barrier (BBB) [16, 17]. Despite their advantages, in vitro studies provide limited insight into the influence of tissue context and the dynamic processes during development, with ECs in vitro even displaying opposite characteristics to those in vivo [18]. To understand cerebrovascular development therefore necessitates in vivo studies (Fig. 1).

Rats and mice have been extensively used for basic and translational cerebrovascular studies due to their similar neuroanatomy to human, detailed genome mapping, and 


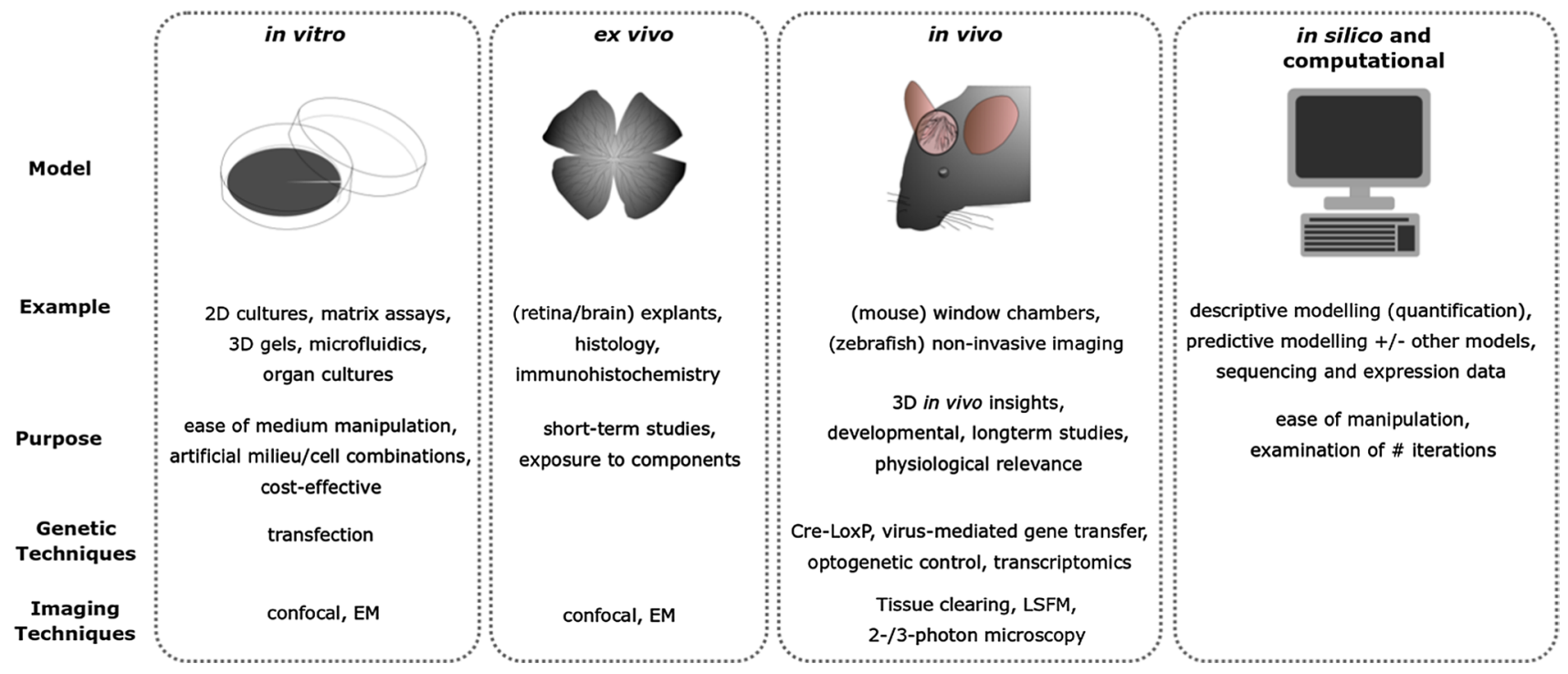

Fig. 1 Summary of models used to study cerebrovascular development

sophisticated murine genetic techniques [19]. The retina provides an excellent, well characterised model to study cerebrovascular ECs. The optic vesicle forms from the CNS in early embryogenesis $[20,21]$ allowing study of the interactions between neurons and cerebral ECs. However, ex vivo retina studies require sacrifice of the animal, preventing in vivo imaging. In utero development and skull formation make direct observation of developmental processes challenging. This was recently addressed by a novel method mouse intravital imaging [22]. Still, imaging of the intracerebral vasculature technically challenging, requiring a surgically-created cranial window. Imaging the cerebral vessels is now possible for several weeks [23-25], with greater imaging depth achieved by 3-photon fluorescence microscopy [26] and long wavelength reflectance confocal microscopy [27]. Despite such improvements in vivo imaging, most rodent studies of cerebral vessels remain histological. Advances such as tissue clearing [28-32] and light sheet fluorescence microscopy (LSFM) [33-35], allow whole brains to be imaged without sectioning. However, tissue processing can introduce artefacts and methods for vascular quantification, especially in 3D, are still limited. Despite this, the mouse remains the model most suitable for sophisticated genetic approaches that provide insights into the mechanisms of cerebrovascular development. These includes vascular-specific crerecombinase [36, 37], virus-mediated gene transfer [38, 39], and optogenetic approaches [40, 41].

Zebrafish are an increasingly used non-mammalian model to study vascular formation and function. The embryos develop rapidly ex utero, making them accessible from the earliest stages of development [42, 43]. This allows genetic constructs to be microinjected into fertilised eggs, facilitating genetic manipulation, and transgenesis. Larval transparency and an array of transgenic reporter lines allows non-invasive observation of organogenesis in real-time. These advantages have made zebrafish an excellent model to observe in vivo cardiovascular development over time [44]. Most studies of zebrafish vascular development have focused on the trunk vasculature that has a simple and stereotypical anatomy, but the mechanisms determining the form and function of the cerebral vessels are now increasingly studied. The cerebral and trunk vasculature form as two separate vascular beds which subsequently merge $[45,46]$. Despite the many advantages of zebrafish it should be noted that studying the adult zebrafish cerebral vasculature is limited by skull formation as in rodents. Thus, studying cerebral blood vessels in $3 \mathrm{D}$ in vivo in any adult species remains a major challenge. In addition, although the zebrafish is readily genetically manipulated to generate mutants and transgenics, the ability to induce tissue-specific gene manipulation is not as well-established as in the mouse.

In addition to in vitro, in situ, and in vivo approaches, in silico computational models have advanced our understanding on cerebrovascular development, dynamics, and disease. This is exemplified by models of cell behaviour depending on growth factors in microenvironments, which are particularly strong when linked to in vivo studies [47-49]. Similarly, large scale modelling, such as in silico studies of haemodynamic forces provide novel insights into cerebrovascular biology and disease [50-52]. To 
establish such predictive models, descriptive models are often required first to enable the establishment of boundary conditions. As such, (bio)medical image analysis and cerebrovascular quantification tools are not only essential to understand vascular biology, but also to allow such modelling approaches [53-56]. These models are complemented by an increasing data availability and analysis on single-cell transcriptomics, cellular diversity, crossspecies diversity as well as regional specializations $[4$, 57-59].

Together, a wide array of tools and models exist to understand, assess, and model cerebrovascular development.

\section{Signalling pathways driving cerebrovascular development}

The key molecular drivers of vasculogenesis, angiogenesis, vessel maturation, arteriovenous specification, and vascular remodelling are well conserved between species (reviewed extensively [60-62]). However, our understanding of these pathways is drawn from a wide range of in vitro and in vivo models, and not all have been well studied in cerebrovascular development. Below we briefly summarise these key pathways and discuss their roles in cerebral vessel development (Table 1).

Table 1 Overview of signalling pathways driving vascular development, their key roles and the vascular territory in which they have been shown to be functioning

\begin{tabular}{|c|c|c|c|c|c|}
\hline Pathway & Main component(s) & Main role(s) & Cerebral vasculature & $\begin{array}{l}\text { Non- } \\
\text { cerebral } \\
\text { vasculature }\end{array}$ & References \\
\hline \multirow[t]{5}{*}{ VEGF } & $V E G F-A$ & Vasculogenesis, angiogenesis & Yes & Yes & {$[65,66]$} \\
\hline & $V E G F-B$ & $\mathrm{BBB}$ formation and vessel maintenance & Yes & & [67-69] \\
\hline & $V E G F-C, V E G F-D$ & Lymphangiogenesis & Yes & Yes & {$[70,71,73-75]$} \\
\hline & $V E G F-3 / F l t 4$ & Angiogenesis & Yes & & {$[77,78]$} \\
\hline & VEGFR-1/Flt1 & "Decoy" receptor & Unknown & Yes & [79-82] \\
\hline Hippo & $Y A P / T A Z$ & $\begin{array}{l}\text { Angiogenesis, tip cell migration and bar- } \\
\text { rierogenesis }\end{array}$ & Yes & Yes & [84-88] \\
\hline Notch & dll4, notch1b, notch3 & $\begin{array}{l}\text { Inhibitory function in vasculogenesis, angi- } \\
\text { ogenesis, arteriovenous differentiation }\end{array}$ & Yes & Yes & {$[89-94,94-105]$} \\
\hline FGF & $F g f-2$ & $\begin{array}{l}\text { Mesodermal angioblasts, angiogenesis, } \\
\text { lymphangiogenesis }\end{array}$ & Unknown & Yes & {$[113-117,169]$} \\
\hline \multirow[t]{3}{*}{$\mathrm{HH}$} & ihh (indian) & Yolks sac angiogenesis & Unknown & Yes & {$[118,121,122]$} \\
\hline & dhh $($ desert $H H)$ & BBB & Yes & & [126] \\
\hline & $\operatorname{shh}($ sonic $H H)$ & EC tubes, arteriovenous differentiation & Unknown & & {$[123-125]$} \\
\hline TGF- $\beta$ & Alk1, Endoglin & EC migration, lumenization & Yes & Yes & {$[61,129-135]$} \\
\hline Wnt & $W n t 7 a / b$ & $\begin{array}{l}\text { EC sprouting, BBB, impacts FGF signal- } \\
\text { ling }\end{array}$ & Yes & & {$[142-146,148,149]$} \\
\hline \multirow[t]{2}{*}{ Neuropilin } & Nrpl & Arteries & Yes & Yes & {$[153,154]$} \\
\hline & Nrp2 & Veins and lymphatics & Yes & Yes & {$[153,154]$} \\
\hline \multirow[t]{3}{*}{ Semaphorins } & Class3 & Inhibition of angiogenesis & Yes & Yes & [164-167] \\
\hline & Class6A & Angiogenesis & Yes & & {$[168]$} \\
\hline & Class7A & Angiogenesis & & Yes & {$[171]$} \\
\hline Netrins & & $\begin{array}{l}\text { EC migration and proliferation, BBB, anti- } \\
\text { inflammatory }\end{array}$ & Yes & Yes & {$[174-180]$} \\
\hline Robo/Slit & Robo4 & $\begin{array}{l}\text { Angiogenesis, cell chemotaxis, neuronal } \\
\text { development }\end{array}$ & Yes & Yes & [183-185] \\
\hline Sprouty & & Inhibition of VEGF and FGF & Yes & & {$[186,187,191]$} \\
\hline PDGF & & $\begin{array}{l}\text { Vessel maturation by mural cell recruit- } \\
\text { ment, vascular stability, neuronal activity, } \\
\text { BBB }\end{array}$ & Yes & Yes & {$[192-198,451]$} \\
\hline Angiopoietin/Tie & & $\begin{array}{l}\text { Vessel maturation by mural cell recruit- } \\
\text { ment, vascular stability }\end{array}$ & Yes & Yes & [199-206] \\
\hline \multirow[t]{2}{*}{ Ephrins } & Ephrin-B2 & Expressed on arteries & Yes & Yes & {$[216,217,221-223]$} \\
\hline & EphB4 & Expressed on veins & Yes & Yes & {$[218,219,221-223]$} \\
\hline
\end{tabular}


The Vascular Endothelial Growth Factor A-E (VEGF A-E) family of ligands are pro-angiogenic guidance cues that induce EC proliferation, migration, and vascular permeability [63, 64], mediated via VEGF receptor (VEGFR) tyrosine kinases (RTK). VEGF-A signalling is mainly mediated by VEGFR-2/Kdr/Flk1, the "master regulator" of angiogenesis required for cerebral and non-cerebral angiogenesis $[65,66]$.

VEGF-B acts via VEGFR-1/flt-1 and Neuropilin 1 to play a role in blood-brain barrier (BBB) formation and cerebral vessel maintenance in rodents $[67,68]$. In zebrafish, VEGF-B is indispensable for neuronal and cerebrovascular development with embryonic lethality upon loss of the duplicated orthologue vegfba, but not vegfbb [69]. VEGF$\mathrm{C}$ and VEGF-D mainly interact with VEGFR-3/Flt4 and promote lymphangiogenesis in vertebrates [70-72]. While VEGF-C is pivotal for embryonic lymphatic development, VEGF-D is required for inflammatory lymphatic growth and the response to brain injury [73, 74]. However, in zebrafish the roles of vegfc and vegfd are less clear-cut, with vegfd required for angiogenesis and facial lymphangiogenesis [75] and vegfc-driven VEGFR-3/Flt4 signalling playing a role in trunk angiogenesis [76].

The complex roles of receptor-based signalling are exemplified by the fact that global loss of VEGFR-3/Flt4 results in reduced cerebral EC developmental angiogenesis in mice [77], while EC specific loss results in hyper-sprouting of hindbrain and retina ECs [78]. In contrast to the above RTKs, VEGFR-1/Flt1 acts as a "decoy" receptor, binding VEGF-A with high affinity, but low RTK activity [79-82]. In zebrafish, flt1 is an important negative regulator for trunk angiogenesis [83], but whether this applies to cerebral ECs remains unclear.

Yes-associated protein (YAP) and its paralog transcriptional coactivator with PDZ-binding motif (TAZ) are Hippo pathway effectors, which mediate VEGF-VEGFR2 signalling during angiogenesis [84]. In mice, YAP/TAZ-CDC42 signalling regulates retinal vascular tip cell migration [85] and loss of YAP/TAZ leads to altered cerebral angiogenesis and vascular barrier formation [86]. Additionally, in zebrafish, YAP plays a role in cerebral and non-cerebral blood vessels maintenance [87] (reviewed in [88]).

Notch signalling counter-balances VEGF signalling, providing inhibitory functions in angiogenesis and cell proliferation [89, 90]. Notch and VEGF signalling co-ordinate tip-stalk-cell formation and angiogenic sprouting, with high VEGFR expression in tip cells and Notch receptor expression in stalk cells [91-95]. Tip and stalk cells of the cerebral vasculature can dynamically shuffle position in vitro and in zebrafish [49]. Alterations in Notch signalling impact cerebrovascular patterning and identity $[96,97]$, demonstrating Notch is essential for cerebrovascular development and maintenance.
Mathematical models have provided insights into tipstalk-cell selection and vascular sprouting. Although some of these models compare computational findings to in vivo data, the impacts of EC microenvironments and vascular territories remain to be modelled in more depth $[47,92,98]$ (for reviews see [99-101]). Notch signalling is also crucial for arterial differentiation and maintenance with conserved functions in different model organisms and vascular beds (cerebral and non-cerebral) [73, 82-84]. Notch dysregulation is common in human genetic cerebrovascular diseases such as Cerebral Autosomal Dominant Arteriopathy with Subcortical Infarcts and Leukoencephalopathy (CADASIL) [105-107] and Cerebral Cavernous Malformation (CCM) $[108,109]$ in which small cerebral capillaries develop, are remodelled, or function abnormally.

Fibroblast Growth Factor 2 (FGF-2) promotes angiogenesis in chick embryo chorioallantoic membrane [110], mouse cornea [111], zebrafish non-cerebral vessels [112, 113], and murine subcutaneous Matrigel plug [114]. Additionally, FGF-2/VEGF-C plays a role in lymphangiogenesis [115]. Whether this applies to cerebrovascular development requires further examination, which may be clinically important, since FGFR1 gain-of-function mutations are found in cerebral glioblastoma [116].

The Hedgehog $(\mathrm{HH})$ morphogen family includes sonic hedgehog (shh), indian hedgehog (ihh), and desert hedgehog (dhh), which all play roles in vascular development (reviewed in [117]). I $\boldsymbol{h} \boldsymbol{h}$ is required for yolk sac blood island formation in mice $[118,119]$, while $\boldsymbol{s h}$ is needed for vascular tube formation in mice, birds and in vitro [120-122]. The role of $\boldsymbol{d} \boldsymbol{h} \boldsymbol{h}$ in angiogenesis is less clear, but $d h h$ produced by cerebral ECs is required for BBB formation [123, 124]. HH impacts via angiopoietin-1 is required for cerebral EC attachment but not arteriovenous differentiation in zebrafish [125], suggesting that $\mathrm{HH}$ is likely to impact cerebrovascular development on multiple spatiotemporal levels.

The Transforming Growth Factor- $\beta$ (TGF- $\beta$ ) family includes TGF- $\beta \mathrm{s}$, bone morphogenetic proteins (BMPs), activins, and inhibins. Their role in angiogenesis is not fully elucidated as impacts are dose-dependent and TGF- $\beta$ component ablation is often embryonically lethal (reviewed in [61, 126, 127]). Alk1 (type I receptor; TGF $\beta R 1$; or activin receptor-like kinase 1, ACVRL1) [128, 129] and Endoglin (type III receptor; TGF $\beta R 3$ ) [130-132] are specifically expressed in EC and are required for both cerebral and noncerebral EC formation. Recent studies in mouse retinae [133, $134]$ and zebrafish non-cerebral vessels $[135,136]$ show that Endoglin plays a crucial role in mouse retinal angiogenesis [133] and is also implicated in hereditary haemorrhagic telangiectasia (HHT) which may cause cerebral cerebrovascular arteriovenous malformations with upregulation of VEGF signalling $[133,134]$. Alk1 regulates EC migration 
in lumenized cerebral vessels [137], and Alk3 is required for cerebral venous identity [138].

Wnt signalling plays important roles in angiogenesis and vascular remodelling [139-142]. Wnt/ $\beta$-catenin signalling is required for CNS, but not non-cerebral, angiogenesis in mice [143]. Wnt regulates FGF activity in cerebrovascular development in zebrafish [144] and Wnt7a/Wnt7b-specific signalling is required for cerebrovascular angiogenesis in both zebrafish [145] and mouse [146]. Moreover, Wnt signalling is essential for BBB formation and maintenance [147-149].

Neuropilin (Nrp) receptors are expressed in specific EC types with Nrp-1 in arteries and Nrp-2 in veins and lymphatics (reviewed in [150, 151]). Nrp-1 mediates murine cerebral EC angiogenesis and lymphangiogenesis $[152,153]$. While it is believed that Nrp-1 impacts angiogenesis via interacting with VEGF, increasing evidence in mice suggests Nrp-1 might impact vascular permeability independently of VEGF $[152,154]$. Conversely, in vitro studies show that VEGF can induce Nrp-1 [155]. Understanding the impact of Nrps is complicated by the finding that the Nrp- 1 cytoplasmic domain is dispensable for cerebral and non-cerebral EC angiogenesis, but promotes arteriovenous separation [156]. Nrp1 and Nrp2 double-knockouts in mice are embryonically lethal, and lack both cerebral and non-cerebral vasculature [157].

In zebrafish, all four Neuropilins play roles in angiogenesis, with loss of nrp1b and nrp2a leading to cerebral vascular abnormalities $[158,159]$. A recent study suggests Nrp-1 signalling is indispensable for vascular development and that Nrp-signals via VEGF [69]. Increasing evidence also suggests Nrp influence cerebral angiogenesis via TGF $\beta$ and PDGF $[127,160]$.

Semaphorins were originally identified as axon-guidance cues but also mediate angiogenesis. Class 3 semaphorins inhibit angiogenesis in both non-cerebral [161-163] and cerebral ECs in mice [164]. While Semaphorin 6A regulates angiogenesis in the mouse retina [165], Semaphorin $7 \boldsymbol{A}$ mediates angiogenesis in mouse non-cerebral ECs [166]. Semaphorins also impact angiogenesis of non-cerebral ECs in the zebrafish $[167,168]$, but cerebral vessels have not been studied.

Netrins are axonal guidance and attraction cues [163, $163]$ and play a role in angiogenesis, influencing EC migration and proliferation in CAM, zebrafish trunk vessel, and mouse retinae [171-173] as well as anti-inflammatory functions [174-176. In the cerebral vasculature, netrins play a role in BBB integrity [170, 177, 178].

The Roundabout receptors (Robo) and Slit ligands impact angiogenesis, EC chemotaxis, and neuronal development (reviewed in [179]). Robo4 is essential for angiogenesis in vivo in the zebrafish trunk vasculature and mouse ex vivo retina [180, 181]. Cerebrovascular roles of Robo/Slit are yet to be defined.
Sprouty ligands inhibit Ras-ERK MAPK signalling, creating a negative feedback loop for VEGF and FGF signalling $[182,183]$ that inhibits angiogenesis. Studies in zebrafish, mice, and human show different Sprouty ligands are expressed in the brain [184-186] (reviewed in [187]), but their roles in cerebrovascular formation are undefined.

Platelet-derived growth factor (PDGF) is a chemoattractant mitogen. PDGF-B and its receptor PDGFR $\beta$ [188-190] are required for recruitment of pericytes to cerebral vessels [191] and play a role in blood-brain-barrier (BBB) development, post-stroke, and neurodegenerative diseases [192-194].

Angiopoietin ligands and their RTKs Tie receptors play crucial roles in mural cell recruitment and vascular stability [195-197]. Angiopoietin-1 promotes vascular stability, while Angiopoietin-2 decreases stability and promotes vascular remodelling [198-202]. An underlying mechanism for this difference in function is differential Tie- 2 receptor phosphorylation [203]. Human EC and mouse data suggests that Tie-1 regulates Tie-2 intracellular trafficking [204]. Angiopoietin-1 regulates cerebrovascular permeability in human brain microvascular endothelial cells in vitro [205], while studies in fish showed that Angiopoietin-1 impacts brain size [206]. Angiopoietin-2 is dysregulated in mouse cerebral cavernous malformation (CCM) [207], but its inhibition rescues arteriovenous malformation (AVM) in a hereditary haemorrhagic telangiectasia (HHT) mouse model [208]. Additionally, macrophage-derived Angiopoietin-Like Protein 2 aggravates post-ischemia inflammation [209] and Angiopoietin like-4 mediates capillary cerebral amyloid angiopathy, a feature of some human neurological diseases [210].

The ephrin-B2 ligand and EphB4 receptor are crucial regulators of vascular morphogenesis (reviewed in [211]). Ephrin-B2 is expressed on arteries and EphB4 on veins. Loss of function results in defective angiogenesis in cerebral vessels in mice [212, 213]. EphB4 modulates VEGFR-2 signalling through phospho-ERK1/2 in cerebral ECs [214, 215]. Ephrin-B2 is pro-angiogenic in mouse cerebral ECs [216], and Ephrins also play a role in neural patterning (reviewed in [217-219]) as well as neuropathologies [220, 221].

\section{The role of blood flow in cerebrovascular development}

Blood flow impacts EC gene expression and cell behaviour via flow-derived forces [222, 223]. Studies in mice show that hemodynamic forces directly impact cerebrovascular topology by remodelling cerebrovascular (cornea [224] and retinal [225]) vessels. Hemodynamic forces appear to impact EC migration rather than cell death in all vascular beds, and Notch signalling regulates this in zebrafish [226] and mice [227-229]. Blood flow also impacts EC gene expression and 
epigenetics, of relevance to cerebrovascular diseases such as aneurysm, stroke, and neurodegeneration [5, 7, 230, 231] but also crucial for stabilization of arterio-venous identity after molecular initiation [213, 232] (reviewed in [233-235]). In zebrafish, although arterio-venous differentiation of trunk vessels is understood in great detail, cerebrovascular identity establishment is less well described [226, 236-239].

Blood flow also plays a crucial role in vascular lumenization. How this is achieved in different vascular beds and in different species is not fully understood. In zebrafish, different mechanisms of non-cerebral vessel lumenization are proposed, including 'vacuole fusion' [240, 241] and 'inverse membrane blebbing' [242] in ISVs, 'lumen ensheathment' in common cardinal veins (CCVs) [243], and 'hollowing' of the dorsal cord [244]. How cerebral vessels are lumenized is unclear and only indirect evidence suggests cerebrovascular lumenization by 'budding' [245]. In mice and human, lumenization is even less well understood and studies suggest 'intracellular vacuoles' and 'cord-hollowing' are potential mechanisms [246-248]. Lastly, blood flow plays a role in brain ventricular expansion [249], indirectly impacting cerebral vessel development via brain morphogenesis.

\section{The role of cilia in angiogenesis}

Immotile primary cilia on EC sense blood flow and are disrupted by shear stress in human ECs [250] as well as on non-cerebral ECs in zebrafish [251] and mice [252, 253]. Loss of primary cilia in mice impairs EC vascular integrity and homeostasis [254] and heart development leading to aneurysms and atherosclerosis [255], while endothelial primary cilia are dispensable for vascular development but are atheroprotective [253]. In zebrafish the subcellular localization of cerebrovascular primary EC cilia is independent of blood flow and cardiac contractions [256]. Primary cilia also impact EC polarization and migratory behaviour in the mouse retina [257] and regulate hematopoietic stem and progenitor cell specification in the zebrafish aorta-gonad mesonephros [258].

Ependymal motile cilia are required for brain development and CSF flow directionality in zebrafish [259]. Similarly in mice, cilia are essential for the brain ependyma and choroid plexus development [260, 261], and adult CSF flow [262].

Loss of cilia in embryonic zebrafish results in cerebrovascular EC defects [256, 257, 263], cerebral haemorrhage $[125,264]$, and reduced arterial vSMCs of non-cerebral vessels [265]. It remains unclear whether cilia loss impacts cerebrovascular vSMC and the BBB. Interestingly, loss of cilia in juvenile and adult zebrafish does not result in gross vascular defects in cerebral and non-cerebral vascular beds [266].

\section{Non-endothelial cells required for cerebrovascular development}

Pericytes and vascular smooth muscle cells (vSMCs) collectively known as vascular mural cells (MCs), ensheath vessels abluminally, providing vascular stability and homeostasis [197, 267, 268]. Previously it was believed that trunk MCs are mesoderm derived, while cerebral MCs are neural crest and mesoderm derived [97, 269]. Recent studies suggests transdifferentiation of macrophages into pericytes, vSMCs, and ECs may contribute to vascular MCs [270-272]. Such transdifferentiation was recently shown in mice [273] but whether this occurs in other species is unknown. With technical advancements in mouse transgenesis and in vivo imaging, it is possible to study cerebral MCs in developing [274] and adult [275] mice, showing that MCs are heterogeneous and structurally plastic. In both zebrafish and mice, impairment of mural cell coverage leads to BBB breakdown [192, 276, 277].

Radial glia, also called astroglia, are neural stem cells, support neuronal migration, and regulate CNS angiogenesis [278-280]. Radial glia, moreover, impact astrocyte differentiation, thus contribute to neurovascular unit functionality [281]. As radial glia in zebrafish harbour high regenerative capacity, zebrafish are a suitable model to study CNS regeneration [282-284].

Astrocytes are specialised cerebral and spinal cord glial cells that ensheath blood vessel with astrocytic end-feet. They provide structural support and as part of the BBB, play a role in tripartite synapse homeostasis and regulate blood flow [285-292]. Astrocytes play a key role in neuron maintenance as well as ionic and osmotic brain homeostasis [293-295]. Increasing evidence suggests astrocytes are a potential link for vascular contributions to cognitive impairment and dementia [294]. A murine study found that neurons, which are ensheathed by astrocytes, form a migration scaffold for blood vessels with astrocyte-derived VEGF being crucial for angiogenesis [296], while another showed that oxygen provided by retinal ECs promotes astrocyte differentiation [297].

The role of immune cells in EC development, inflammation, repair, and cancer has gained increased attention. Macrophages are of particular clinical interest as tumour associated macrophages (TAMs) are associated with cancer prognosis [298, 299] and TAMs contribute to brain malignancies [300-302] and glioma progression [303]. In intracerebral haemorrhage (ICH), macrophages play a role in the secondary post-stroke phase and represent a therapeutic target $[304,305]$. While mice have been the main model of choice to examine cerebral haemorrhage, zebrafish models also allow study of ICH [306-308]. Macrophages also monitor neuronal activity and impact neuronal structural 
remodelling in mice [309] and zebrafish [310], and thus may impact cerebral ECs indirectly via neurons. Macrophages can act as cellular chaperones guiding cerebral vessel formation [311] and clear apoptotically pruned cerebral ECs [312] during zebrafish development. During tissue repair, zebrafish macrophages mediate vascular repair in cerebral ECs [313] and have been shown to migrate faster when in contact with trunk vessels compared with non-vascular cells [314], though whether this applies to cerebral ECs is unknown.

Many studies on neutrophils examine their roles in cancer and the tumour microenvironment (review [315, 316]). Neutrophils play a role in VEGF signalling and matrix-metalloproteinase secretion, contributing to tumour angiogenesis, and metastasis in mice [317,318], while inhibition of VEGF signalling decreased tumour angiogenesis but increased neutrophil-mediated metastasis in zebrafish [319]. Very few publications examine the role of neutrophils in cerebrovascular development, and neutrophils do not enter the brain under normal conditions [320].

Neurons and ECs use common guidance molecules for repulsion and retraction (e.g. ephrins, semaphorins, slits and netrins, see above), and share functional and molecular similarities in pathfinding, growth, migration, and differentiation [321-323]. This structural parallel growth of vessels and neurons, called neurovascular congruency [324], is important in shaping mouse cerebral vessels [322, 325-327], but it has been suggested that vessels and neurons are independently patterned in more complex 3D tissues such as mouse whiskers [328]. Additionally, studies in murine noncerebral ECs showed that motor-neurons impact vascular patterning in the spinal cord [329], while blood vessels are important regulators of neural stem cell properties [330]. Zebrafish studies of cerebral neurovascular congruency suggest the vasculature is required for hindbrain development [331] and ganglia projections [332]. Conversely ablation of oxytocin in the hypothalamo-neurohypophyseal system results in defects of vascular patterning [333] and motor neurons were shown to be essential for vascular pathfinding in non-cerebral vessels [334]. Besides these structural and molecular interactions, cerebrovascular ECs and neurons interact functionally via neurovascular coupling (NVC; or functional hyperemia). NVC increases local cerebral blood flow in response to increased neuronal activity, orchestrated by ECs, neurons, astrocytes, and vSMCs [335-337]. Evidence in human and rodents showed that NVC is impaired with age [338-341] and neurodegenerative diseases such as Alzheimer's [8, 342-345].

How NVC develops in humans is currently unclear due to the difficulty in age-matching of patients and the lack of long-term studies [346, 347]. Studies in rats showed absent or negative blood-oxygen-level-dependent (BOLD) signals in functional magnetic resonance imaging (fMRI) with increased BOLD signals 2-3 weeks postnatally [348, 349]. In zebrafish NVC develops between 6-to-8dpf and high glucose exposure impairs NVC, mirroring human diabetes [350, 351].

\section{The role of the extracellular matrix in cerebrovascular development}

The vascular basal lamina (BL) is a thin, dense cross-linked network of extracellular matrix (ECM) proteins forming a thin barrier (mainly laminin, collagen IV, nidogen/ entactin, and heparin sulfate proteoglycans (HSPGs)). It is synthesised by ECs, astrocytes, and pericytes (reviewed in [352-354]). Previously the BL was considered a passive scaffold providing structural support for ECs, astrocytes, and pericytes by adhering to the BL via integrins and proteoglycans. New interest emerged due to its role in angiogenesis, BBB integrity, and pathology (reviewed in [355, $356]$ ) and the finding that BL-composition is highly tissuespecific and altered in disease [357-360]. Laminins are pivotal for basement membrane integrity in the eye [361], retinal angiogenesis [362], and BBB integrity [363, 364]. A murine study suggested the role of BL laminins in retinal angiogenesis is mediated via recruitment of microglia [365]. Laminin/integrin-induced Dll4/Notch-signalling is crucial in tip cell formation in retinal cerebrovascular ECs in mice [366] and in vitro in primary human ECs [367]. Collagen IV is essential for organism-wide BL maintenance but dispensable for initial assembly [368]. Loss of Col4a1 leads to cerebral-specific haemorrhage and porencephaly $[369,370]$. In zebrafish, loss of collagen IV impacts axonogenesis [371], but its impact on ECs is unknown. Nidogen/entactin links the laminin and collagen IV networks [372]. Loss of nidogen-1 results in neurological defects and structural alteration of brain capillaries with BL thinning in mice [373], while loss of nidogen-2 resulted in no obvious phenotypic effect [374]. Murine nidogen-1 and nidogen- 2 co-regulate and are enriched in ECs [375], but this did not examine cerebral ECs. Cardiac and pulmonary haemorrhage upon nidogen loss is reported, but again no data on cerebrovascular ECs is available [376]. In zebrafish four nidogen family members (nidla, nidlb, nid2a and nid2b) are predicted to exist, but only loss of nidla has been studied with a phenotype of reduced body length [377]. Three different HSPGs are found in the vascular BL, namely perlecan, agrin, and collagen XVII [378]. Perlecan modulates cell adhesion, proliferation, and growth factor signalling [379]. Perlecan is lost within hours after cerebral ischemic stroke in non-human primates [380]. In mice, perlecan is not required for early angiogenesis, but loss of perlecan results in cerebrovascular defects, brain hemorrhage [381], and profound cardiovascular defects $[382,383]$. This suggests perlecan plays 
a role in angiogenesis and/or vascular maintenance, especially in cerebral vessels. In contrast, the $\mathrm{C}$ terminus of perlecan, named "endorepellin", inhibits angiogenesis [384]. Morpholino studies in zebrafish suggested loss of perlecan results in defects of somitogenesis and angiogenesis, exemplified by loss of circulation in cerebral and trunk vessels. Although the authors showed that perlecan (heparan sulfate proteoglycan 2/ hspg2) impacts EC proliferation and migration in trunk vessels, it is unclear whether this is the case for cerebrovascular ECs [385, 386]. Agrin plays a role in the development of the body posterior, CNS [387], and retina in zebrafish [388], but the role in EC and cerebrovascular ECspecific is unclear. In mice, agrin promotes heart regeneration [389] and contributes to cerebrovascular EC adherens junctions and thus EC barrier properties [390], and agrin is required for BBB formation in chicken and rat [391]. Other ECM components, such as metalloproteases, metalloproteinases, and ADAMS, play a role in angiogenic sprouting/ remodelling as well as the angiogenic switch during carcinogenesis (see reviews [392-394]). Their cerebrovascular-specific roles are far from understood although MMP-2 and MMP-9 are upregulated after cerebral ischemia in nonhuman primates [395, 396].

\section{The blood brain barrier, choroid plexus and cerebral lymphatic development}

The brain undergoes major structural developmental remodelling, by invagination in mammals and eversion in zebrafish [397]. Higher vertebrates (birds, amphibians, and mammals) have four brain ventricles, while fish have two [398, 399]. Each ventricle has a choroid plexus [398], harbouring ependymal cells, which are the major source of cerebrospinal fluid (CSF) [400, 401], with CSF potentially contributed by liquid flux through capillary walls [402, 403].

The CSF serves a protective role and provides the CNS with nutrients and waste removal. Factors that contribute to CSF movement are respiration [404, 405] and head movement [406] in humans. Murine studies show cilia play a role in ependymal flow [407, 408], while studies in zebrafish show contraction, body movement, and cilia all play a role in CSF flow [259].

The blood-brain-barrier $(B B B)$ protects the brain from pathogens, neurotoxic molecules, and lipophilic elements $[293,409]$. The BBB is formed by inter-EC junctions and specialized transporters of cerebrovascular ECs, to provide a barrier between blood and interstitial fluid [1]. Recent transcriptional profiling studies in mice examined cell types and zonation of the cerebral vasculature [4] and how the BBB is impacted in models of CNS disease (stroke, multiple sclerosis, traumatic brain injury and seizure) [410]. In all the examined CNS diseases cerebral ECs shift towards non-cerebral EC expression patterns. These studies also examined non-cerebral tissues, allowing examination of cerebrovascular-specific EC properties. The ability to study BBB formation in vivo and over long periods of time made zebrafish a favourable model for barrierogenesis [411-415], with recent work showing that barrierogenesis and cerebrovascular angiogenesis occur in parallel [416].

Following the discovery of meningeal lymphatics in mice [417, 418], similar findings in zebrafish [419-421], non-human primates, and humans followed [422]. In zebrafish the meningeal lymphatics regulate meningeal angiogenesis [419]. Similarly, the brain parenchyma was thought to be widely devoid of parenchymal lymphatics [423], but this was challenged by the finding that lymphatics invade brain parenchyma in response to injury to guide vascular regeneration [424]. The concepts of cerebral waste clearance were additionally challenged by the finding of the "glymphatic system" in mice in 2012 [ 425 , 426]. This clearance system is made of perivascular channels formed by astroglial cells and is mainly active during sleep and reduces with age (reviews [427-430]).

\section{Concluding remarks and future perspectives}

With the availability of different models our knowledge of cerebral vascular development has increased substantially. Although the general mechanisms and molecular regulation of ECs development and function are now understood in great detail [60-62, 431-433], the degree to which these are conserved between models and between the cerebral and other vascular territories is far less complete. More sophisticated experimental models such as organoids, 3D cell co-culturing systems, 3D printing, as well as in silico computational models [434-437] will aid our mechanistic understanding of the diversity of cerebrovascular ECs.

It is increasingly clear that individual mechanisms and cellular components interact with each other. The field would benefit from understanding these interactions in different vascular beds, and how these change in development and disease.

Complementary to these new models, further improvements of imaging techniques and image analysis approaches allow for cutting edge data acquisition, and performance of meaningful objective quantifications which can handle large datasets. Medical imaging techniques are being applied to pre-clinical studies, such as Optical projection tomography (OPT) [438-440], Magnetic Resonance Imaging (MRI) [441, 442], Optical Coherence Tomography and Angiography (OCTA) and Nuclear Magnetic Resonance (NMR) [443], or combining cutting edge 
techniques such as LSFM and OPT [444]. Importantly, imaging techniques are evolving from descriptive to quantitative [55, 445] and integrating information from other tissue [446-449]. This quantification will also impact future drug screening and pharmacodynamics studies, helping to identify strategies to treat human cerebrovascular diseases.

Acknowledgements This work was supported by a University of Sheffield, Department of Infection, Immunity and Cardiovascular Disease, Imaging and Modelling Node Studentship and a Bridging Fund from the Insigneo Institute for in silico Medicine, University of Sheffield awarded to ECK. We apologize to colleagues whose work was not cited in this review.

Author contributions Project Administration, ECK, and TJAC; Writing-Original Draft, ECK; Writing-Review and Editing, all authors contributed equally.

\section{Compliance with ethical standards}

Conflict of interest The authors declare thatthey have no conflict of interest.

Consent for publication Not applicable.

Consent to participate Not applicable.

Ethics approval Not applicable.

Open Access This article is licensed under a Creative Commons Attribution 4.0 International License, which permits use, sharing, adaptation, distribution and reproduction in any medium or format, as long as you give appropriate credit to the original author(s) and the source, provide a link to the Creative Commons licence, and indicate if changes were made. The images or other third party material in this article are included in the article's Creative Commons licence, unless indicated otherwise in a credit line to the material. If material is not included in the article's Creative Commons licence and your intended use is not permitted by statutory regulation or exceeds the permitted use, you will need to obtain permission directly from the copyright holder. To view a copy of this licence, visit http://creativecommons.org/licenses/by/4.0/.

\section{References}

1. Abbott NJ, Patabendige AAK, Dolman DEM, Yusof SR, Begley DJ (2010) Structure and function of the blood-brain barrier. Neurobiol Dis 37(1):13-25. https://doi.org/10.1016/j. nbd.2009.07.030

2. Huntley MA, Bien-Ly N, Daneman R, Watts RJ (2014) Dissecting gene expression at the blood-brain barrier. Front Neurosci. https://doi.org/10.3389/fnins.2014.00355

3. Kugler EC et al (2019) Cerebrovascular endothelial cells form transient Notch-dependent cystic structures in zebrafish. EMBO Rep 20(8):e47047. https://doi.org/10.15252/embr.201847047

4. Vanlandewijck M et al (2018) A molecular atlas of cell types and zonation in the brain vasculature. Nature 554(7693):475-480. https://doi.org/10.1038/nature25739
5. Sweeney MD, Kisler K, Montagne A, Toga AW, Zlokovic BV (2018) The role of brain vasculature in neurodegenerative disorders. Nat Neurosci 21(10):1318-1331. https://doi.org/10.1038/ s41593-018-0234-x

6. Sweeney MD, Sagare AP, Zlokovic BV (2018) Blood-brain barrier breakdown in Alzheimer disease and other neurodegenerative disorders. Nat Rev Neurol 14(3):133-150. https://doi. org/10.1038/nrneurol.2017.188

7. Sweeney MD et al (2019) Vascular dysfunction-The disregarded partner of Alzheimer's disease. Alzheimer's Dementia 15(1):158-167. https://doi.org/10.1016/j.jalz.2018.07.222

8. Kisler K, Nelson AR, Montagne A, Zlokovic BV (2017) Cerebral blood flow regulation and neurovascular dysfunction in Alzheimer disease. Nat Rev Neurosci 18(7):419-434. https:// doi.org/10.1038/nrn.2017.48

9. Bakker ENTP et al (2016) Lymphatic clearance of the brain: perivascular, paravascular and significance for neurodegenerative diseases. Cell Mol Neurobiol 36(2):181-194. https://doi. org/10.1007/s10571-015-0273-8

10. Visanji NP, Lang AE, Munoz DG (2018) Lymphatic vasculature in human dural superior sagittal sinus: implications for neurodegenerative proteinopathies. Neurosci Lett 665:18-21. https://doi. org/10.1016/j.neulet.2017.11.001

11. Weller RO, Carare RO (2018) Chapter 30-lymphatic drainage of the CNS and its role in neuroinflammation and neurodegenerative disease. In: Minagar A (ed) Neuroinflammation, 2nd edn. Cambridge, Academic Press, pp 601-617

12. Santos JV, Vandenberghe D, Lobo M, Freitas A (2020) Cost of cardiovascular disease prevention: towards economic evaluations in prevention programs. Ann Transl Med. https://doi. org/10.21037/atm.2020.01.20

13. AlMalki WH, Shahid I, Mehdi AY, Hafeez MH (2014) Assessment methods for angiogenesis and current approaches for its quantification. Indian J Pharmacol 46(3):251-256. https://doi. org/10.4103/0253-7613.132152

14. Staton CA, Stribbling SM, Tazzyman S, Hughes R, Brown NJ, Lewis CE (2004) Current methods for assaying angiogenesis in vitro and in vivo. Int J Exp Pathol 85(5):233-248. https:// doi.org/10.1111/j.0959-9673.2004.00396.x

15. Osaki T, Sivathanu V, Kamm RD (2018) Engineered 3D vascular and neuronal networks in a microfluidic platform. Sci Rep 8(1):1-13. https://doi.org/10.1038/s41598-018-23512-1

16. Adriani G, Ma D, Pavesi A, Kamm RD, Goh ELK (2017) A 3D neurovascular microfluidic model consisting of neurons, astrocytes and cerebral endothelial cells as a blood-brain barrier. Lab Chip 17(3):448-459. https://doi.org/10.1039/C6LC0 $0638 \mathrm{H}$

17. Campisi M, Shin Y, Osaki T, Hajal C, Chiono V, Kamm RD (2018) 3D self-organized microvascular model of the human blood-brain barrier with endothelial cells, pericytes and astrocytes. Biomaterials 180:117-129. https://doi.org/10.1016/j. biomaterials.2018.07.014

18. Kim $T$ et al (2018) In situ transcriptome characteristics are lost following culture adaptation of adult cardiac stem cells. Sci Rep 8(1):1-9. https://doi.org/10.1038/s41598-018-30551-1

19. Vandamme TF (2014) Use of rodents as models of human diseases. J Pharm Bioallied Sci 6(1):2-9. https://doi. org/10.4103/0975-7406.124301

20. Tual-Chalot S, Allinson KR, Fruttiger M, Arthur HM (2013) Whole mount immunofluorescent staining of the neonatal mouse retina to investigate angiogenesis in vivo. J Vis Exp. https://doi. org/10.3791/50546

21. Purves D et al (2001) The Retina. In: Neuroscience. 2nd edition. [Online]. https://www.ncbi.nlm.nih.gov/books/NBK10885/. Accessed 04 Nov 2019 
22. Huang $Q$ et al (2020) Intravital imaging of mouse embryos. Science 368(6487):181-186. https://doi.org/10.1126/science.aba02 10

23. Heo C et al (2016) A soft, transparent, freely accessible cranial window for chronic imaging and electrophysiology. Sci Rep 6(1):1-11. https://doi.org/10.1038/srep27818

24. Koletar MM, Dorr A, Brown ME, McLaurin J, Stefanovic B (2019) Refinement of a chronic cranial window implant in the rat for longitudinal in vivo two-photon fluorescence microscopy of neurovascular function. Sci Rep 9(1):1-12. https://doi. org/10.1038/s41598-019-41966-9

25. Shabir O et al (2020) Enhanced cerebral blood volume under normobaric hyperoxia in the J20-hAPP mouse model of Alzheimer's disease. Sci Rep. https://doi.org/10.1038/s41598-020-64334-4

26. Liu $\mathrm{H}$ et al (2019) Visualizing astrocytes in the deep mouse brain in vivo. J Biophotonics 12(7):e201800420. https://doi. org/10.1002/jbio.201800420

27. Xia F, Wu C, Sinefeld D, Li B, Qin Y, Xu C (2018) In vivo labelfree confocal imaging of the deep mouse brain with long-wavelength illumination. Biomed. Opt. Express BOE 9(12):65456555. https://doi.org/10.1364/BOE.9.006545

28. Richardson DS, Lichtman JW (2015) Clarifying tissue clearing. Cell 162(2):246-257. https://doi.org/10.1016/j.cell.2015.06.067

29. Lugo-Hernandez E et al (2017) 3D visualization and quantification of microvessels in the whole ischemic mouse brain using solvent-based clearing and light sheet microscopy. J Cereb Blood Flow Metab. https://doi.org/10.1177/0271678X17698970

30. Erturk A, Lafkas D, Chalouni C (2014) Imaging cleared intact biological systems at a cellular level by 3DISCO. J Vis Exp. https ://doi.org/10.3791/51382

31. Rocha MD et al (2019) Tissue clearing and light sheet microscopy: imaging the unsectioned adult zebra finch brain at cellular resolution. Front Neuroanat. https://doi.org/10.3389/fnana 2019.00013

32. Ueda HR et al (2020) Tissue clearing and its applications in neuroscience. Nat Rev Neurosci. https://doi.org/10.1038/s4158 3-019-0250-1

33. Huisken J, Swoger J, Del Bene F, Wittbrodt J, Stelzer EHK (2004) Optical sectioning deep inside live embryos by selective plane illumination microscopy. Science 305(5686):1007-1009. https://doi.org/10.1126/science.1100035

34. Stelzer EHK (2015) Light-sheet fluorescence microscopy for quantitative biology. Nat Methods 12(1):23-26. https://doi. org/10.1038/nmeth.3219

35. Power RM, Huisken J (2017) A guide to light-sheet fluorescence microscopy for multiscale imaging. Nat Methods 14(4):360-373. https://doi.org/10.1038/nmeth.4224

36. Alva JA et al (2006) VE-Cadherin-Cre-recombinase transgenic mouse: a tool for lineage analysis and gene deletion in endothelial cells. Dev Dyn 235(3):759-767. https://doi.org/10.1002/ dvdy. 20643

37. Hübner $\mathrm{K}$ et al (2018) Wnt/ $/$-catenin signaling regulates VEcadherin-mediated anastomosis of brain capillaries by counteracting S1pr1 signaling. Nat Commun. https://doi.org/10.1038/ s41467-018-07302-x

38. Liu $\mathrm{Y}$ et al (2020) UnaG as a reporter in adeno-associated virusmediated gene transfer for biomedical imaging. J Biophotonics 13(12):e202000182. https://doi.org/10.1002/jbio.202000182

39. Fazal Z, Hosaka K, Manfredsson F, Hoh B (2018) Introducing a novel method of intravascular adeno-associated virus-mediated gene delivery. Virology (Hyderabad), vol. 2, no. 1. https://www. ncbi.nlm.nih.gov/pmc/articles/PMC6258074/. Accessed 23 Jan 2021
40. Tong L et al (2021) Imaging and optogenetic modulation of vascular mural cells in the live brain. Nat Protocols. https://doi. org/10.1038/s41596-020-00425-w

41. Tennant KA, Taylor SL, White ER, Brown CE (2017) Optogenetic rewiring of thalamocortical circuits to restore function in the stroke injured brain. Nat Commun. https://doi.org/10.1038/ ncomms 15879

42. Holtzman NG, Iovine MK, Liang JO, Morris J (2016) Learning to fish with genetics: a primer on the vertebrate model Danio rerio. Genetics 203(3):1069-1089. https://doi.org/10.1534/genet ics.116.190843

43. Kimmel CB, Ballard WW, Kimmel SR, Ullmann B, Schilling TF (1995) Dev Dyn 203(3):253-310. https://doi.org/10.1002/ aja.1002030302

44. Gut P, Reischauer S, Stainier DYR, Arnaout R (2017) Little fish, big data: zebrafish as a model for cardiovascular and metabolic disease. Physiol Rev 97(3):889-938. https://doi.org/10.1152/ physrev.00038.2016

45. Kimura E, Isogai S, Hitomi J (2015) Integration of vascular systems between the brain and spinal cord in zebrafish. Devel Biol 406(1):40-51. https://doi.org/10.1016/j.ydbio.2015.07.015

46. Proulx K, Lu A, Sumanas S (2010) Cranial vasculature in zebrafish forms by angioblast cluster-derived angiogenesis. Dev Biol 348(1):34-46. https://doi.org/10.1016/j.ydbio.2010.08.036

47. Bentley K, Gerhardt H, Bates PA (2008) Agent-based simulation of notch-mediated tip cell selection in angiogenic sprout initialisation. J Theor Biol 250(1):25-36. https://doi.org/10.1016/j. jtbi.2007.09.015

48. Kur E et al (2016) Temporal modulation of collective cell behavior controls vascular network topology. eLife Sci 5:e13212. https ://doi.org/10.7554/eLife.13212

49. Jakobsson L et al (2010) Endothelial cells dynamically compete for the tip cell position during angiogenic sprouting. Nat Cell Biol 12(10):943-953. https://doi.org/10.1038/ncb2103

50. Blanco PJ, Watanabe SM, Passos MARF, Lemos PA, Feijóo RA (2015) An anatomically detailed arterial network model for onedimensional computational hemodynamics. IEEE Trans Biomed Eng 62(2):736-753. https://doi.org/10.1109/TBME.2014.23645 22

51. Sforza DM, Putman CM, Cebral JR (2012) Computational fluid dynamics in brain aneurysms. Int J Numer Methods Biomed Eng 28(6-7):801-808. https://doi.org/10.1002/cnm.1481

52. Marzo A et al (2011) Computational hemodynamics in cerebral aneurysms: the effects of modeled versus measured boundary conditions. Ann Biomed Eng 39(2):884-896. https://doi. org/10.1007/s10439-010-0187-z

53. Kirst $C$ et al (2020) Mapping the fine-scale organization and plasticity of the brain vasculature. Cell 180(4):780-795.e25. https ://doi.org/10.1016/j.cell.2020.01.028

54. Todorov MI et al (2020) Machine learning analysis of whole mouse brain vasculature. Nat Methods. https://doi.org/10.1038/ s41592-020-0792-1

55. Daetwyler S, Günther U, Modes CD, Harrington K, Huisken J (2019) Multi-sample SPIM image acquisition, processing and analysis of vascular growth in zebrafish. Development. https:// doi.org/10.1242/dev.173757

56. Kugler EC et al (2020) 3D quantification of zebrafish cerebrovascular architecture by automated image analysis of light sheet fluorescence microscopy datasets. bioRxiv. https://doi. org/10.1101/2020.08.06.239905

57. Zhang $Y$ et al (2014) An RNA-sequencing transcriptome and splicing database of glia, neurons, and vascular cells of the cerebral cortex. J Neurosci 34(36):11929-11947. https://doi. org/10.1523/JNEUROSCI.1860-14.2014 
58. Song HW, Foreman KL, Gastfriend BD, Kuo JS, Palecek SP, Shusta EV (2020) Transcriptomic comparison of human and mouse brain microvessels. Sci Rep. https://doi.org/10.1038/ s41598-020-69096-7

59. Ximerakis $\mathrm{M}$ et al (2019) Single-cell transcriptomic profiling of the aging mouse brain. Nat Neurosci. https://doi.org/10.1038/ s41593-019-0491-3

60. Eilken HM, Adams RH (2010) Dynamics of endothelial cell behavior in sprouting angiogenesis. Curr Opin Cell Biol 22(5):617-625. https://doi.org/10.1016/j.ceb.2010.08.010

61. Patel-Hett S, D'Amore PA (2011) Signal transduction in vasculogenesis and developmental angiogenesis. Int J Dev Biol 55:353-363. https://doi.org/10.1387/ijdb.103213sp

62. Rossant J, Howard L (2002) Signaling pathways in vascular development. Annu Rev Cell Dev Biol 18(1):541-573. https:// doi.org/10.1146/annurev.cellbio.18.012502.105825

63. Ferrara N, Gerber H-P, LeCouter J (2003) The biology of VEGF and its receptors. Nat Med 9(6):669-676. https://doi.org/10.1038/ nm0603-669

64. Simons M, Gordon E, Claesson-Welsh L (2016) Mechanisms and regulation of endothelial VEGF receptor signalling. Nat Rev Mol Cell Biol 17(10):611-625. https://doi.org/10.1038/nrm.2016.87

65. Covassin LD, Villefranc JA, Kacergis MC, Weinstein BM, Lawson ND (2006) Distinct genetic interactions between multiple Vegf receptors are required for development of different blood vessel types in zebrafish. Proc Natl Acad Sci USA 103(17):65546559. https://doi.org/10.1073/pnas.0506886103

66. Ruhrberg $C$ et al (2002) Spatially restricted patterning cues provided by heparin-binding VEGF-A control blood vessel branching morphogenesis. Genes Dev 16(20):2684-2698. https://doi. org/10.1101/gad.242002

67. Nag S, Eskandarian MR, Davis J, Eubanks JH (2002) Differential expression of vascular endothelial growth factor-A (VEGFA) and VEGF-B after brain injury. J Neuropathol Exp Neurol 61(9):778-788. https://doi.org/10.1093/jnen/61.9.778

68. Zhang $\mathrm{F}$ et al (2009) VEGF-B is dispensable for blood vessel growth but critical for their survival, and VEGF-B targeting inhibits pathological angiogenesis. Proc Natl Acad Sci USA 106(15):6152-6157. https://doi.org/10.1073/pnas.0813061106

69. Jensen LD et al (2015) VEGF-B-Neuropilin-1 signaling is spatiotemporally indispensable for vascular and neuronal development in zebrafish. Proc Natl Acad Sci USA 112(44):E5944-5953. https://doi.org/10.1073/pnas.1510245112

70. Joukov $\mathrm{V}$ et al (1996) A novel vascular endothelial growth factor, VEGF-C, is a ligand for the Flt4 (VEGFR-3) and KDR (VEGFR2) receptor tyrosine kinases. EMBO J 15(2):290-298

71. Karkkainen MJ et al (2004) Vascular endothelial growth factor $\mathrm{C}$ is required for sprouting of the first lymphatic vessels from embryonic veins. Nat Immunol 5(1):74-80. https://doi. org/10.1038/ni1013

72. Shinriki $S$ et al (2011) Interleukin-6 signalling regulates vascular endothelial growth factor-C synthesis and lymphangiogenesis in human oral squamous cell carcinoma. J Pathol 225(1):142-150. https://doi.org/10.1002/path.2935

73. Bui $\mathrm{HM}$ et al (2016) Proteolytic activation defines distinct lymphangiogenic mechanisms for VEGFC and VEGFD. J Clin Invest. 126(6):2167-2180. https://doi.org/10.1172/JCI83967

74. Nag S, Manias J, Eubanks JH, Stewart DJ (2019) Increased expression of vascular endothelial growth factor-D following brain injury. Int J Mol Sci 20(7):1594. https://doi.org/10.3390/ ijms20071594

75. Bower NI et al (2017) Vegfd modulates both angiogenesis and lymphangiogenesis during zebrafish embryonic development. Development 144(3):507-518. https://doi.org/10.1242/dev.14696 9
76. Hogan BM et al (2009) Vegfc/Flt4 signalling is suppressed by Dl14 in developing zebrafish intersegmental arteries. Development 136(23):4001-4009. https://doi.org/10.1242/dev.039990

77. Tammela $\mathrm{T}$ et al (2008) Blocking VEGFR-3 suppresses angiogenic sprouting and vascular network formation. Nature 454(7204):656-660. https://doi.org/10.1038/nature07083

78. Tammela $\mathrm{T}$ et al (2011) VEGFR-3 controls tip to stalk conversion at vessel fusion sites by reinforcing Notch signalling. Nat Cell Biol 13(10):1202-1213. https://doi.org/10.1038/ncb2331

79. Boucher JM, Clark RP, Chong DC, Citrin KM, Wylie LA, Bautch VL (2017) Dynamic alterations in decoy VEGF receptor-1 stability regulate angiogenesis. Nat Commun 8:15699. https://doi. org/10.1038/ncomms 15699

80. Chappell JC, Taylor SM, Ferrara N, Bautch VL (2009) Local guidance of emerging vessel sprouts requires soluble Flt1. Dev Cell 17(3):377-386. https://doi.org/10.1016/j.devce 1.2009.07.011

81. Chappell JC et al (2016) Flt-1 (VEGFR-1) coordinates discrete stages of blood vessel formation. Cardiovasc Res. 111(1):84-93. https://doi.org/10.1093/cvr/cvw091

82. Kappas NC et al (2008) The VEGF receptor Flt-1 spatially modulates Flk-1 signaling and blood vessel branching. J Cell Biol 181(5):847-858. https://doi.org/10.1083/jcb.200709114

83. Krueger J et al (2011) Flt1 acts as a negative regulator of tip cell formation and branching morphogenesis in the zebrafish embryo. Development 138(10):2111-2120. https://doi.org/10.1242/ dev.063933

84. Wang X et al (2017) YAP/TAZ Orchestrate VEGF signaling during developmental angiogenesis. Dev Cell 42(5):462-478. e7. https://doi.org/10.1016/j.devcel.2017.08.002

85. Sakabe $M$ et al (2017) YAP/TAZ-CDC42 signaling regulates vascular tip cell migration. PNAS 114(41):10918-10923. https ://doi.org/10.1073/pnas.1704030114

86. Kim J et al (2017) YAP/TAZ regulates sprouting angiogenesis and vascular barrier maturation. J Clin Invest 127(9):3441-3461. https://doi.org/10.1172/JCI93825

87. Nakajima $\mathrm{H}$ et al (2017) Flow-dependent endothelial YAP regulation contributes to vessel maintenance. Dev Cell 40(6):523-536. e6. https://doi.org/10.1016/j.devcel.2017.02.019

88. Boopathy GTK, Hong W (2019) Role of hippo pathway-YAP/ TAZ signaling in angiogenesis. Front Cell Dev Biol. https://doi. org/10.3389/fcell.2019.00049

89. Bray SJ (2006) Notch signalling: a simple pathway becomes complex. Nat Rev Mol Cell Biol 7(9):678-689. https://doi. org/10.1038/nrm2009

90. Thomas J-L et al (2013) Interactions between VEGFR and Notch signaling pathways in endothelial and neural cells. Cell Mol Life Sci 70(10):1779-1792. https://doi.org/10.1007/s0001 8-013-1312-6

91. Benedito R et al (2009) The notch ligands Dll4 and Jagged1 have opposing effects on angiogenesis. Cell 137(6):1124-1135. https ://doi.org/10.1016/j.cell.2009.03.025

92. Bentley K, Mariggi G, Gerhardt H, Bates PA (2009) Tipping the balance: robustness of tip cell selection, migration and fusion in angiogenesis. PLoS Comput Biol 5(10):e1000549. https://doi. org/10.1371/journal.pcbi.1000549

93. Savage AM et al (2019) tmem33 is essential for VEGF-mediated endothelial calcium oscillations and angiogenesis. Nat Commun 10(1):732. https://doi.org/10.1038/s41467-019-08590-7

94. Siekmann AF, Lawson ND (2007) Notch signalling limits angiogenic cell behaviour in developing zebrafish arteries. Nature 445(7129):781-784. https://doi.org/10.1038/nature05577

95. Siekmann AF, Affolter M, Belting H-G (2013) The tip cell concept ten years after: new players tune in for a common theme. Exp Cell Res 319(HASH(0x9242d98)):1255-1263 
96. Bussmann J, Wolfe SA, Siekmann AF (2011) Arterial-venous network formation during brain vascularization involves hemodynamic regulation of chemokine signaling. Development. https ://doi.org/10.1242/dev.059881

97. Wang Y, Pan L, Moens CB, Appel B (2014) Notch3 establishes brain vascular integrity by regulating pericyte number. Development 141(2):307-317. https://doi.org/10.1242/dev.096107

98. Palm MM, Dallinga MG, van Dijk E, Klaassen I, Schlingemann RO, Merks RMH (2016) Computational screening of tip and stalk cell behavior proposes a role for apelin signaling in sprout progression. PLoS ONE 11(11):e0159478. https://doi. org/10.1371/journal.pone.0159478

99. Finley SD, Chu L-H, Popel AS (2015) Computational systems biology approaches to anti-angiogenic cancer therapeutics. Drug Discov Today 20(2):187-197. https://doi.org/10.1016/j.drudi s.2014.09.026

100. Peirce SM, Mac Gabhann F, Bautch VL (2012) Integration of experimental and computational approaches to sprouting angiogenesis. Curr Opin Hematol 19(3):184-191. https://doi. org/10.1097/MOH.0b013e3283523ea6

101. Scianna M, Bell CG, Preziosi L (2013) A review of mathematical models for the formation of vascular networks. J Theor Biol 333:174-209. https://doi.org/10.1016/j.jtbi.2013.04.037

102. Duarte A et al (2004) Dosage-sensitive requirement for mouse Dl14 in artery development. Genes Dev 18(20):2474-2478. https ://doi.org/10.1101/gad.1239004

103. Lawson ND et al (2001) Notch signaling is required for arterialvenous differentiation during embryonic vascular development. Development 128(19):3675-3683

104. Sacilotto N et al (2013) Analysis of Dll4 regulation reveals a combinatorial role for Sox and Notch in arterial development. Proc Natl Acad Sci USA. https://doi.org/10.1073/pnas.13008 05110

105. Joutel A et al (1996) Notch3 mutations in CADASIL, a hereditary adult-onset condition causing stroke and dementia. Nature 383(6602):707-710. https://doi.org/10.1038/383707a0

106. Joutel A et al (2000) The ectodomain of the Notch3 receptor accumulates within the cerebrovasculature of CADASIL patients. J Clin Invest 105(5):597-605. https://doi.org/10.1172/JCI8047

107. Wang MM (2018) CADASIL. Handb Clin Neurol 148:733-743. https://doi.org/10.1016/B978-0-444-64076-5.00047-8

108. Renz M et al (2015) Regulation of $\beta 1$ integrin-Klf2-mediated angiogenesis by CCM proteins. Dev Cell 32(2):181-190. https ://doi.org/10.1016/j.devcel.2014.12.016

109. You C, Sandalcioglu IE, Dammann P, Felbor U, Sure U, Zhu Y (2013) Loss of CCM3 impairs DLL4-Notch signalling: implication in endothelial angiogenesis and in inherited cerebral cavernous malformations. J Cell Mol Med 17(3):407-418. https://doi. org $/ 10.1111 / \mathrm{jcmm} .12022$

110. Ribatti D et al (1998) Role of basic fibroblast growth factor in the formation of the capillary plexus in the chick embryo chorioallantoic membrane. An in situ hybridization, immunohistochemical and ultrastructural study. J Submicrosc Cytol Pathol 30(1):127-136

111. Seghezzi G et al (1998) Fibroblast Growth Factor-2 (FGF-2) Induces Vascular Endothelial Growth Factor (VEGF) expression in the endothelial cells of forming capillaries: an autocrine mechanism contributing to angiogenesis. J Cell Biol 141(7):16591673. https://doi.org/10.1083/jcb.141.7.1659

112. De Smet $F$ et al (2014) Fibroblast growth factor signaling affects vascular outgrowth and is required for the maintenance of blood vessel integrity. Chem Biol 21(10):1310-1317. https://doi. org/10.1016/j.chembiol.2014.07.018

113. Nicoli S, Sena GD, Presta M (2009) Fibroblast growth factor 2-induced angiogenesis in zebrafish: the zebrafish yolk membrane
(ZFYM) angiogenesis assay. J Cell Mol Med 13(8b):2061-2068. https://doi.org/10.1111/j.1582-4934.2008.00432.x

114. Coltrini D, Di Salle E, Ronca R, Belleri M, Testini C, Presta M (2013) Matrigel plug assay: evaluation of the angiogenic response by reverse transcription-quantitative PCR. Angiogenesis 16(2):469-477. https://doi.org/10.1007/s10456-012-9324-7

115. Cao R et al (2012) Collaborative interplay between FGF-2 and VEGF-C promotes lymphangiogenesis and metastasis. PNAS 109(39):15894-15899. https://doi.org/10.1073/pnas.1208324109

116. Rand $\mathrm{V}$ et al (2005) Sequence survey of receptor tyrosine kinases reveals mutations in glioblastomas. PNAS 102(40):1434414349. https://doi.org/10.1073/pnas.0507200102

117. Chapouly C, Guimbal S, Hollier P-L, Renault M-A (2019) Role of Hedgehog signaling in vasculature development, differentiation, and maintenance. Int J Mol Sci. https://doi.org/10.3390/ ijms20123076

118. Byrd $\mathrm{N}$ et al (2002) Hedgehog is required for murine yolk sac angiogenesis. Development 129(2):361-372

119. Dyer MA, Farrington SM, Mohn D, Munday JR, Baron MH (2001) Indian hedgehog activates hematopoiesis and vasculogenesis and can respecify prospective neurectodermal cell fate in the mouse embryo. Development 128(10):1717-1730

120. Kanda S, Mochizuki Y, Suematsu T, Miyata Y, Nomata K, Kanetake H (2003) Sonic hedgehog induces capillary morphogenesis by endothelial cells through phosphoinositide 3-kinase. J Biol Chem 278(10):8244-8249. https://doi.org/10.1074/jbc.M2106 35200

121. Kolesová H, Roelink H, Grim M (2008) Sonic hedgehog is required for the assembly and remodeling of branchial arch blood vessels. Dev Dyn 237(7):1923-1934. https://doi.org/10.1002/ dvdy. 21608

122. Vokes SA et al (2004) Hedgehog signaling is essential for endothelial tube formation during vasculogenesis. Development 131(17):4371-4380. https://doi.org/10.1242/dev.01304

123. Caradu $\mathrm{C}$ et al (2018) Restoring endothelial function by targeting desert hedgehog downstream of Klf2 improves critical limb ischemia in adults. Circ. Res. 123(9):1053-1065. https://doi. org/10.1161/CIRCRESAHA.118.313177

124. Alvarez JI et al (2011) The Hedgehog pathway promotes bloodbrain barrier integrity and CNS immune quiescence. Science 334(6063):1727-1731. https://doi.org/10.1126/science.1206936

125. Lamont RE, Vu W, Carter AD, Serluca FC, MacRae CA, Childs SJ (2010) Hedgehog signaling via angiopoietin1 is required for developmental vascular stability. Mech Dev 127(3):159-168. https://doi.org/10.1016/j.mod.2010.02.001

126. Guerrero PA, McCarty JH (2017) TGF- $\beta$ activation and signaling in angiogenesis. Physiol Pathol Angiogen Signal Mech Target Therapy. https://doi.org/10.5772/66405

127. Kofler N, Simons M (2016) The expanding role of Neuropilin: regulation of vascular TGF $\beta$ and PDGF signaling. Curr Opin Hematol 23(3):260-267. https://doi.org/10.1097/MOH.00000 00000000233

128. Roelen BA, van Rooijen MA, Mummery CL (1997) Expression of ALK-1, a type 1 serine/threonine kinase receptor, coincides with sites of vasculogenesis and angiogenesis in early mouse development. Dev Dyn 209(4):418-430. https ://doi.org/10.1002/(SICI)1097-0177(199708)209:4\%3c418 ::AID-AJA9\%3e3.0.CO;2-L

129. Roelen BAJ, Lin HY, Knežević V, Freund E, Mummery CL (1994) Expression of TGF- $\beta$ s and their receptors during implantation and organogenesis of the mouse embryo. Dev Biol 166(2):716-728. https://doi.org/10.1006/dbio.1994.1350

130. Cheifetz S et al (1992) Endoglin is a component of the transforming growth factor-beta receptor system in human endothelial cells. J Biol Chem 267(27):19027-19030 
131. Gougos A, Letarte M (1990) Primary structure of endoglin, an RGD-containing glycoprotein of human endothelial cells. J Biol Chem 265(15):8361-8364

132. Lebrin $\mathrm{F}$ et al (2004) Endoglin promotes endothelial cell proliferation and TGF-beta/ALK1 signal transduction. EMBO J 23(20):4018-4028. https://doi.org/10.1038/sj.emboj.7600386

133. Gallardo-Vara E, Tual-Chalot S, Botella LM, Arthur HM, Bernabeu C (2018) Soluble endoglin regulates expression of angiogenesis-related proteins and induction of arteriovenous malformations in a mouse model of hereditary hemorrhagic telangiectasia. Dis Models Mech 11(9):dmm034397. https://doi.org/10.1242/ dmm.034397

134. Jia Y-C, Fu J-Y, Huang P, Zhang Z-P, Chao B, Bai J (2020) Characterization of endothelial cells associated with cerebral arteriovenous malformation. Neuropsychiatr Dis Treat 16:1015-1022. https://doi.org/10.2147/NDT.S248356

135. Sugden WW et al (2017) Endoglin controls blood vessel diameter through endothelial cell shape changes in response to haemodynamic cues. Nat Cell Biol 19(6):653-665. https://doi. org/10.1038/ncb3528

136. Zhang D, Zhou F, Zhao X, Liu B, Chen J, Yang J (2019) Endoglin is a conserved regulator of vasculogenesis in zebrafishimplications for hereditary haemorrhagic telangiectasia. Biosci Rep 39(5):BSR20182320. https://doi.org/10.1042/BSR2018232 0

137. Rochon ER, Menon PG, Roman BL (2016) Alk1 controls arterial endothelial cell migration in lumenized vessels. Development 143(14):2593-2602. https://doi.org/10.1242/dev.135392

138. Neal A et al (2019) Venous identity requires BMP signalling through ALK3. Nat Commun. https://doi.org/10.1038/s4146 7-019-08315-w

139. Goodwin AM, D'Amore PA (2002) Wnt signaling in the vasculature. Angiogenesis 5(1-2):1-9. https://doi.org/10.1023/a:10215 63510866

140. Reis M, Liebner S (2013) Wnt signaling in the vasculature. Exp Cell Res 319(9):1317-1323. https://doi.org/10.1016/j.yexcr .2012.12.023

141. Olsen JJ et al (2017) The role of Wnt signalling in angiogenesis. Clin Biochem Rev 38(3):131-142

142. Elisabetta D, Michael K (2010) The role of Wnt signaling in physiological and pathological angiogenesis. Circ Res 107(8):943-952. https://doi.org/10.1161/CIRCRESAHA 110.223750

143. Daneman R, Agalliu D, Zhou L, Kuhnert F, Kuo CJ, Barres BA (2009) Wnt/ $\beta$-catenin signaling is required for CNS, but not non-CNS, angiogenesis. PNAS 106(2):641-646. https://doi. org/10.1073/pnas.0805165106

144. Dyer $\mathrm{C}$ et al (2014) A bi-modal function of Wnt signalling directs an FGF activity gradient to spatially regulate neuronal differentiation in the midbrain. Development 141(1):63-72. https://doi. org/10.1242/dev.099507

145. Vanhollebeke B et al (2015) Tip cell-specific requirement for an atypical Gpr124- and Reck-dependent Wnt/beta-catenin pathway during brain angiogenesis. Elife. https://doi.org/10.7554/eLife .06489

146. Stenman JM, Rajagopal J, Carroll TJ, Ishibashi M, McMahon J, McMahon AP (2008) Canonical Wnt signaling regulates organ-specific assembly and differentiation of CNS vasculature. Science 322(5905):1247-1250. https://doi.org/10.1126/scien ce. 1164594

147. Polakis P (2008) Formation of the blood-brain barrier: Wnt signaling seals the deal. J Cell Biol 183(3):371-373. https://doi. org/10.1083/jcb.200810040

148. Zhou Y, Nathans J (2014) Gpr124 controls CNS angiogenesis and blood-brain barrier integrity by promoting ligand-specific canonical Wnt signaling. Dev Cell 31(2):248-256. https://doi. org/10.1016/j.devcel.2014.08.018

149. Liebner $\mathrm{S}$ et al (2008) $\mathrm{Wnt} / \beta$-catenin signaling controls development of the blood-brain barrier. J Cell Biol 183(3):409-417. https://doi.org/10.1083/jcb.200806024

150. Kofler NM, Simons M (2015) Angiogenesis versus arteriogenesis: neuropilin 1 modulation of VEGF signaling. F1000Prime Rep. https://doi.org/10.12703/P7-26

151. Schwarz Q, Ruhrberg C (2010) Neuropilin, you gotta let me know. Cell Adh Migr 4(1):61-66

152. Gelfand MV et al (2014) Neuropilin-1 functions as a VEGFR2 co-receptor to guide developmental angiogenesis independent of ligand binding. eLife 3:e03720. https://doi.org/10.7554/eLife .03720

153. Gu C et al (2003) Neuropilin-1 conveys semaphorin and VEGF signaling during neural and cardiovascular development. Dev Cell 5(1):45-57. https://doi.org/10.1016/S1534-5807(03)00169 $-2$

154. Roth L et al (2016) Neuropilin-1 mediates vascular permeability independently of vascular endothelial growth factor receptor-2 activation. Sci Signal 9(425):ra42. https://doi.org/10.1126/scisi gnal.aad3812

155. Vedanta M et al (2018) VEGF (Vascular Endothelial Growth Factor) induces NRP1 (Neuropilin-1) cleavage via ADAMs (a Disintegrin and Metalloproteinase) 9 and 10 to generate novel carboxy-terminal NRP1 fragments that regulate angiogenic signaling. Arterioscler Thromb Vasc Biol 38(8):1845-1858. https:// doi.org/10.1161/ATVBAHA.118.311118

156. Fantin A, Schwarz Q, Davidson K, Normando EM, Denti L, Ruhrberg C (2011) The cytoplasmic domain of neuropilin 1 is dispensable for angiogenesis, but promotes the spatial separation of retinal arteries and veins. Development 138(19):4185-4191. https://doi.org/10.1242/dev.070037

157. Takashima S et al (2002) Targeting of both mouse neuropilin-1 and neuropilin-2 genes severely impairs developmental yolk sac and embryonic angiogenesis. Proc Natl Acad Sci USA 99(6):3657-3662. https://doi.org/10.1073/pnas.022017899

158. Lee P, Goishi K, Davidson AJ, Mannix R, Zon L, Klagsbrun M (2002) Neuropilin-1 is required for vascular development and is a mediator of VEGF-dependent angiogenesis in zebrafish. Proc Natl Acad Sci USA 99(16):10470-10475. https://doi. org/10.1073/pnas.162366299

159. Martyn U, Schulte-Merker S (2004) Zebrafish neuropilins are differentially expressed and interact with vascular endothelial growth factor during embryonic vascular development. Dev Dyn 231(1):33-42. https://doi.org/10.1002/dvdy.20048

160. Hirota $S$ et al (2015) Neuropilin 1 balances $\beta 8$ integrin-activated TGF $\beta$ signaling to control sprouting angiogenesis in the brain. Development 142(24):4363-4373. https://doi.org/10.1242/ dev.113746

161. Acevedo LM, Barillas S, Weis SM, Göthert JR, Cheresh DA (2008) Semaphorin 3A suppresses VEGF-mediated angiogenesis yet acts as a vascular permeability factor. Blood 111(5):26742680. https://doi.org/10.1182/blood-2007-08-110205

162. Maione $\mathrm{F}$ et al (2009) Semaphorin $3 \mathrm{~A}$ is an endogenous angiogenesis inhibitor that blocks tumor growth and normalizes tumor vasculature in transgenic mouse models. J Clin Invest 119(11):3356-3372. https://doi.org/10.1172/JCI36308

163. Junji $\mathrm{M}$ et al (2010) Inhibition of semaphorin as a novel strategy for therapeutic angiogenesis. Circ Res 106(2):391-398. https:// doi.org/10.1161/CIRCRESAHA.109.210815

164. Serini G et al (2003) Class 3 semaphorins control vascular morphogenesis by inhibiting integrin function. Nature 424(6947):391-397. https://doi.org/10.1038/nature01784 
165. Segarra $M$ et al (2012) Semaphorin $6 A$ regulates angiogenesis by modulating VEGF signaling. Blood 120(19):4104-4115. https:// doi.org/10.1182/blood-2012-02-410076

166. Hu S, Liu Y, You T, Zhu L (2018) Semaphorin 7A promotes VEGFA/VEGFR2-mediated angiogenesis and intraplaque neovascularization in ApoE-/- Mice. Front Physiol. https://doi. org/10.3389/fphys.2018.01718

167. Shoji W, Isogai S, Sato-Maeda M, Obinata M, Kuwada JY (2003) Semaphorin3a1 regulates angioblast migration and vascular development in zebrafish embryos. Development 130(14):32273236. https://doi.org/10.1242/dev.00516

168. Torres-Vázquez J et al (2004) Semaphorin-plexin signaling guides patterning of the developing vasculature. Dev Cell 7(1):117-123. https://doi.org/10.1016/j.devcel.2004.06.008

169. Park KW et al (2004) The axonal attractant Netrin-1 is an angiogenic factor. PNAS 101(46):16210-16215. https://doi. org/10.1073/pnas.0405984101

170. Podjaski C et al (2015) Netrin 1 regulates blood-brain barrier function and neuroinflammation. Brain 138(6):1598. https://doi. org/10.1093/brain/awv092

171. Castets $\mathrm{M}$ et al (2009) Inhibition of endothelial cell apoptosis by netrin-1 during angiogenesis. Dev Cell 16(4):614-620. https:// doi.org/10.1016/j.devcel.2009.02.006

172. Freitas C, Larrivée B, Eichmann A (2008) Netrins and UNC5 receptors in angiogenesis. Angiogenesis 11(1):23-29. https://doi. org/10.1007/s10456-008-9096-2

173. Wilson BD et al (2006) Netrins promote developmental and therapeutic angiogenesis. Science 313(5787):640-644. https:// doi.org/10.1126/science.1124704

174. Grenz A et al (2011) Partial netrin-1 deficiency aggravates acute kidney injury. PLoS ONE 6(5):e14812. https://doi.org/10.1371/ journal.pone.0014812

175. Rosenberger P et al (2009) Hypoxia-inducible factor-dependent induction of netrin-1 dampens inflammation caused by hypoxia. Nat Immunol 10(2):195-202. https://doi.org/10.1038/ni.1683

176. Zhang H, Vreeken D, Bruikman CS, van Zonneveld AJ, van Gils JM (2018) Understanding netrins and semaphorins in mature endothelial cell biology. Pharmacol Res 137:1-10. https://doi. org/10.1016/j.phrs.2018.09.015

177. Zongyi X et al (2017) Netrin-1 preserves blood-brain barrier integrity through deleted in colorectal cancer/focal adhesion kinase/RhoA signaling pathway following subarachnoid hemorrhage in rats. J Am Heart Assoc 6(5):e005198. https://doi. org/10.1161/JAHA.116.005198

178. Yu J et al (2017) Netrin-1 ameliorates blood-brain barrier impairment secondary to ischemic stroke via the activation of PI3K pathway. Front Neurosci 11:1-10. https://doi. org/10.3389/fnins.2017.00700

179. Tong M, Jun T, Nie Y, Hao J, Fan D (2019) The role of the slit/ robo signaling pathway. J Cancer 10(12):2694-2705. https:// doi.org/10.7150/jca.31877

180. Bedell VM et al (2005) roundabout4 is essential for angiogenesis in vivo. PNAS 102(18):6373-6378. https://doi.org/10.1073/ pnas.0408318102

181. Jones CA et al (2008) Robo4 stabilizes the vascular network by inhibiting pathologic angiogenesis and endothelial hyperpermeability. Nat Med 14(4):448-453. https://doi.org/10.1038/ nm1742

182. Impagnatiello M-A, Weitzer S, Gannon G, Compagni A, Cotten M, Christofori G (2001) Mammalian sprouty-1 and -2 are membrane-anchored phosphoprotein inhibitors of growth factor signaling in endothelial cells. J Cell Biol 152(5):10871098. https://doi.org/10.1083/jcb.152.5.1087

183. Mason JM, Morrison DJ, Basson MA, Licht JD (2006) Sprouty proteins: multifaceted negative-feedback regulators of receptor tyrosine kinase signaling. Trends Cell Biol 16(1):45-54. https -//doi.org/10.1016/j.tcb.2005.11.004

184. Fürthauer M, Reifers F, Brand M, Thisse B, Thisse C (2001) sprouty 4 acts in vivo as a feedback-induced antagonist of FGF signaling in zebrafish. Development 128(12):2175-2186

185. Taniguchi K et al (2009) Sprouty4 deficiency potentiates Ras-independent angiogenic signals and tumor growth. Cancer Sci 100(9):1648-1654. https://doi.org/10.111 $1 / \mathrm{j} .1349-7006.2009 .01214 . x$

186. Wietecha MS et al (2010) Sprouty2 downregulates angiogenesis during mouse skin wound healing. Am J Physiol Heart Circul Physiol 300(2):H459-H467. https://doi.org/10.1152/ ajpheart.00244.2010

187. Cabrita MA, Christofori G (2003) Sprouty proteins: antagonists of endothelial cell signaling and more. Thromb Haemost 90(10):586-590. https://doi.org/10.1160/TH03-04-0217

188. Cao R et al (2002) Angiogenesis stimulated by PDGF-CC, a novel member in the PDGF family, involves activation of PDGFR- $\alpha \alpha$ and $-\alpha \beta$ receptors. FASEB J 16(12):1575-1583. https://doi.org/10.1096/fj.02-0319com

189. Mamer SB et al (2017) Discovery of high-affinity PDGF-VEGFR interactions: redefining RTK dynamics. Sci Rep 7(1):1-14. https ://doi.org/10.1038/s41598-017-16610-z

190. Nissen LJ et al (2007) Angiogenic factors FGF2 and PDGFBB synergistically promote murine tumor neovascularization and metastasis. J Clin Invest 117(10):2766-2777. https://doi. org/10.1172/JCI32479

191. Hellstrom M, Lindahl P, Abramsson A, Betsholtz C (1999) Role of PDGF-B and PDGFR-beta in recruitment of vascular smooth muscle cells and pericytes during embryonic blood vessel formation in the mouse. Development 126(14):3047-3055

192. Armulik A et al (2010) Pericytes regulate the blood-brain barrier. Nature 468(7323):557-561. https://doi.org/10.1038/nature09522

193. Nahar K, Bertuzzi G, Vanlandewijck M, Keller A, Betsholtz C, Andaloussi Mäe M (2019) Endothelium-derived PDGF-B is essential for adult brain pericyte and vascular smooth muscle cell maintenance. http://urn.kb.se/resol ve?urn=urn:nbn:se:uu:diva-380087. Accessed 14 Nov 2019

194. Shen J et al (2019) PDGFR- $\beta$ restores blood-brain barrier functions in a mouse model of focal cerebral ischemia. J Cereb Blood Flow Metab 39(8):1501-1515. https://doi.org/10.1177/02716 $78 X 18769515$

195. Aplin AC, Fogel E, Nicosia RF (2010) MCP-1 promotes mural cell recruitment during angiogenesis in the aortic ring model. Angiogenesis 13(3):219-226. https://doi.org/10.1007/s1045 6-010-9179-8

196. Davis $\mathrm{S}$ et al (1996) Isolation of angiopoietin-1, a ligand for the TIE2 receptor, by secretion-trap expression cloning. Cell 87(7):1161-1169. https://doi.org/10.1016/S0092-8674(00)81812 $-7$

197. Gaengel K, Genové G, Armulik A, Betsholtz C (2009) Endothelial-mural cell signaling in vascular development and angiogenesis. Arterioscler Thromb Vasc Biol 29(5):630-638. https://doi. org/10.1161/ATVBAHA.107.161521

198. Benest AV et al (2013) Angiopoietin-2 is critical for cytokineinduced vascular leakage. PLoS ONE 8(8):e70459. https://doi. org/10.1371/journal.pone.0070459

199. Eklund L, Kangas J, Saharinen P (2017) Angiopoietin-tie signalling in the cardiovascular and lymphatic systems. Clin Sci (Lond) 131(1):87-103. https://doi.org/10.1042/CS20160129

200. Fiedler U et al (2006) Angiopoietin-2 sensitizes endothelial cells to TNF- $\alpha$ and has a crucial role in the induction of inflammation. Nat Med 12(2):235-239. https://doi.org/10.1038/nm1351

201. Jeansson $M$ et al (2011) Angiopoietin-1 is essential in mouse vasculature during development and in response to injury. J Clin Invest 121(6):2278-2289. https://doi.org/10.1172/JCI46322 
202. Thurston G et al (2000) Angiopoietin-1 protects the adult vasculature against plasma leakage. Nat Med 6(4):460-463. https:// doi.org/10.1038/74725

203. Maisonpierre PC et al (1997) Angiopoietin-2, a natural antagonist for tie 2 that disrupts in vivo angiogenesis. Science 277(5322):55-60. https://doi.org/10.1126/science.277.5322.55

204. Korhonen EA et al (2016) Tie1 controls angiopoietin function in vascular remodeling and inflammation. J Clin Invest 126(9):3495-3510. https://doi.org/10.1172/JCI84923

205. Siddiqui MR, Mayanil CS, Kim KS, Tomita T (2015) Angiopoietin-1 regulates brain endothelial permeability through PTPN-2 mediated tyrosine dephosphorylation of occludin. PLoS ONE 10(6):e0130857. https://doi.org/10.1371/journal.pone.0130857

206. Chen Y-C, Harrison PW, Kotrschal A, Kolm N, Mank JE, Panula P (2015) Expression change in angiopoietin-1 underlies change in relative brain size in fish. Proc R Soc B Biol Sci 282(1810):20150872. https://doi.org/10.1098/rspb.2015.0872

207. Zhou HJ et al (2016) Endothelial exocytosis of angiopoietin-2 resulting from CCM3 deficiency contributes to cerebral cavernous malformation. Nat Med 22(9):1033-1042. https://doi. org/10.1038/nm.4169

208. Crist AM et al (2019) Angiopoietin-2 inhibition rescues arteriovenous malformation in a Smad4 hereditary hemorrhagic telangiectasia mouse model. Circulation 139(17):2049-2063. https:// doi.org/10.1161/CIRCULATIONAHA.118.036952

209. Amadatsu T et al (2016) Macrophage-derived angiopoietin-like protein 2 exacerbates brain damage by accelerating acute inflammation after ischemia-reperfusion. PLoS ONE 11(11):e0166285. https://doi.org/10.1371/journal.pone.0166285

210. Chakraborty A et al (2018) Angiopoietin like-4 as a novel vascular mediator in capillary cerebral amyloid angiopathy. Brain 141(12):3377-3388. https://doi.org/10.1093/brain/awy274

211. Klein R (2012) Eph/ephrin signalling during development. Development 139(22):4105-4109. https://doi.org/10.1242/ dev.074997

212. Gerety SS, Anderson DJ (2002) Cardiovascular ephrinB2 function is essential for embryonic angiogenesis. Development 129(6): 1397-1410

213. Wang HU, Chen ZF, Anderson DJ (1998) Molecular distinction and angiogenic interaction between embryonic arteries and veins revealed by ephrin-B2 and its receptor Eph-B4. Cell 93(5):741-753

214. Groppa E et al (2018) EphrinB2/EphB4 signaling regulates nonsprouting angiogenesis by VEGF. EMBO Rep 19(5):e45054. https://doi.org/10.15252/embr.201745054

215. Sawamiphak $\mathrm{S}$ et al (2010) Ephrin-B2 regulates VEGFR2 function in developmental and tumour angiogenesis. Nature 465(7297):487-491. https://doi.org/10.1038/nature08995

216. Wang $Y$ et al (2010) Ephrin-B2 controls VEGF-induced angiogenesis and lymphangiogenesis. Nature 465(7297):483-486. https://doi.org/10.1038/nature09002

217. Adams RH (2002) Vascular patterning by Eph receptor tyrosine kinases and ephrins. Semin Cell Dev Biol 13(1):55-60. https:// doi.org/10.1006/scdb.2001.0289

218. Holder N, Klein R (1999) Eph receptors and ephrins: effectors of morphogenesis. Development 126(10):2033-2044

219. Wilkinson DG (2001) Multiple roles of EPH receptors and ephrins in neural development. Nat Rev Neurosci 2(3):155-164. https://doi.org/10.1038/35058515

220. Coucha M, Barrett AC, Elgebaly M, Ergul A, Abdelsaid M (2019) Inhibition of Ephrin-B2 in brain pericytes decreases cerebral pathological neovascularization in diabetic rats. PLoS ONE 14(1):e0210523. https://doi.org/10.1371/journal.pone.0210523

221. Xing $\mathrm{S}$ et al (2018) EphrinB2 activation enhances angiogenesis, reduces amyloid- $\beta$ deposits and secondary damage in thalamus at the early stage after cortical infarction in hypertensive rats. J Cereb Blood Flow Metab. https://doi.org/10.1177/0271678X18 769188

222. Baeyens N, Schwartz MA (2016) Biomechanics of vascular mechanosensation and remodeling. Mol Biol Cell 27(1):7-11. https://doi.org/10.1091/mbc.E14-11-1522

223. Campinho P, Vilfan A, Vermot $\mathbf{J}$ (2020) Blood flow forces in shaping the vascular system: a focus on endothelial cell behavior. Front Physiol. https://doi.org/10.3389/fphys.2020.00552

224. Wang Y, Jin Y, Laviña B, Jakobsson L (2018) Characterization of multi-cellular dynamics of angiogenesis and vascular remodelling by intravital imaging of the wounded mouse cornea. Sci Rep. https://doi.org/10.1038/s41598-018-28770-7

225. Franco CA et al (2015) Dynamic endothelial cell rearrangements drive developmental vessel regression. PLoS Biol 13(4):e1002125. https://doi.org/10.1371/journal.pbio.1002125

226. Weijts B et al (2018) Blood flow-induced Notch activation and endothelial migration enable vascular remodeling in zebrafish embryos. Nat Commun 9(1):5314. https://doi.org/10.1038/s4146 7-018-07732-7

227. Lobov IB et al (2011) The Dll4/Notch pathway controls postangiogenic blood vessel remodeling and regression by modulating vasoconstriction and blood flow. Blood 117(24):6728-6737. https://doi.org/10.1182/blood-2010-08-302067

228. Phng L-K et al (2009) Nrarp coordinates endothelial notch and Wnt signaling to control vessel density in angiogenesis. Dev Cell 16(1):70-82. https://doi.org/10.1016/j.devcel.2008.12.009

229. Souilhol C, Harmsen MC, Evans PC, Krenning G (2018) Endothelial-mesenchymal transition in atherosclerosis. Cardiovasc Res 114(4):565-577. https://doi.org/10.1093/cvr/cvx253

230. Nouri A et al (2019) 3D bifurcations characterization for intra-cranial aneurysms prediction. In: Medical imaging 2019: image processing, vol. 10949, p 109491T. doi: https://doi. org/10.1117/12.2504626.

231. Seiler A et al (2019) The relationship between blood flow impairment and oxygen depletion in acute ischemic stroke imaged with magnetic resonance imaging. J Cereb Blood Flow Metab 39(3):454-465. https://doi.org/10.1177/0271678X17732448

232. Obi $\mathrm{S}$ et al (2009) Fluid shear stress induces arterial differentiation of endothelial progenitor cells. J Appl Physiol 106(1):203211. https://doi.org/10.1152/japplphysiol.00197.2008

233. Chien S (2007) Mechanotransduction and endothelial cell homeostasis: the wisdom of the cell. Am J Physiol Heart Circ Physiol 292(3):H1209-1224. https://doi.org/10.1152/ajpheart.01047 .2006

234. Culver JC, Dickinson ME (2010) The effects of hemodynamic force on embryonic development. Microcirculation 17(3):164178. https://doi.org/10.1111/j.1549-8719.2010.00025.x

235. Urner S, Kelly-Goss M, Peirce SM, Lammert E (2018) Chapter six-mechanotransduction in blood and lymphatic vascular development and disease. In: Khalil RA (ed) Advances in pharmacology, vol 81. Academic Press, Cambridge, pp 155-208

236. Geudens I et al (2019) Artery-vein specification in the zebrafish trunk is pre-patterned by heterogeneous Notch activity and balanced by flow-mediated fine-tuning. Development 146(16):dev181024. https://doi.org/10.1242/dev.181024

237. Gore AV, Monzo K, Cha YR, Pan W, Weinstein BM (2012) Vascular Development in the Zebrafish. Cold Spring Harb Perspect Med. https://doi.org/10.1101/cshperspect.a006684

238. Red-Horse K, Siekmann AF (2019) Veins and arteries build hierarchical branching patterns differently: bottom-up versus top-down. BioEssays 41(3):1800198. https://doi.org/10.1002/ bies. 201800198 
239. Swift MR, Weinstein BM (2009) Arterial-venous specification during development. Circ Res 104(5):576-588. https://doi. org/10.1161/CIRCRESAHA.108.188805

240. Blum Y, Belting H-G, Ellertsdottir E, Herwig L, Lüders F, Affolter M (2008) Complex cell rearrangements during intersegmental vessel sprouting and vessel fusion in the zebrafish embryo. Dev Biol 316(2):312-322. https://doi.org/10.1016/j. ydbio.2008.01.038

241. Kamei M, Saunders WB, Bayless KJ, Dye L, Davis GE, Weinstein BM (2006) Endothelial tubes assemble from intracellular vacuoles in vivo. Nature 442(7101):453-456. https://doi. org/10.1038/nature04923

242. Gebala V, Collins R, Geudens I, Phng L-K, Gerhardt H (2016) Blood flow drives lumen formation by inverse membrane blebbing during angiogenesis in vivo. Nat Cell Biol 18(4):ncb3320. https://doi.org/10.1038/ncb3320

243. Helker CSM et al (2013) The zebrafish common cardinal veins develop by a novel mechanism: lumen ensheathment. Development 140(13):2776-2786. https://doi.org/10.1242/dev.091876

244. Jin S-W, Beis D, Mitchell T, Chen J-N, Stainier DYR (2005) Cellular and molecular analyses of vascular tube and lumen formation in zebrafish. Development 132(23):5199-5209. https:// doi.org/10.1242/dev.02087

245. Huisken J, Stainier DYR (2009) Selective plane illumination microscopy techniques in developmental biology. Development 136(12):1963-1975. https://doi.org/10.1242/dev.022426

246. Davis GE, Camarillo CW (1996) An $\alpha 2 \beta 1$ integrin-dependent pinocytic mechanism involving intracellular vacuole formation and coalescence regulates capillary lumen and tube formation in three-dimensional collagen matrix. Exp Cell Res 224(1):39-51. https://doi.org/10.1006/excr.1996.0109

247. Pelton JC, Wright CE, Leitges M, Bautch VL (2014) Multiple endothelial cells constitute the tip of developing blood vessels and polarize to promote lumen formation. Development 141(21):4121-4126. https://doi.org/10.1242/dev.110296

248. Strilić B et al (2009) The molecular basis of vascular lumen formation in the developing mouse aorta. Dev Cell 17(4):505-515. https://doi.org/10.1016/j.devcel.2009.08.011

249. Lowery LA, Sive H (2005) Initial formation of zebrafish brain ventricles occurs independently of circulation and requires the nagie oko and snakehead/atp1a1a.1 gene products. Development 132(9):2057-2067. https://doi.org/10.1242/dev.01791

250. Iomini C, Tejada K, Mo W, Vaananen H, Piperno G (2004) Primary cilia of human endothelial cells disassemble under laminar shear stress. J Cell Biol 164(6):811-817. https://doi.org/10.1083/ jcb.200312133

251. Goetz JG et al (2014) Endothelial cilia mediate low flow sensing during zebrafish vascular development. Cell Rep 6(5):799-808. https://doi.org/10.1016/j.celrep.2014.01.032

252. ten Dijke P, Egorova AD, Goumans M-JTH, Poelmann RE, Hierck BP (2012) TGF- $\beta$ Signaling in endothelial-to-mesenchymal transition: the role of shear stress and primary cilia. Sci Signal 5(212):pt2. https://doi.org/10.1126/scisignal.2002722

253. Dinsmore C, Reiter JF (2016) Endothelial primary cilia inhibit atherosclerosis. EMBO Rep 17(2):156-166. https://doi. org/10.15252/embr.201541019

254. Egorova AD et al (2011) Lack of primary cilia primes shearinduced endothelial-to-mesenchymal transition. Circ Res 108(9):1093-1101. https://doi.org/10.1161/CIRCRESAHA .110 .231860

255. Pala R, Jamal M, Alshammari Q, Nauli SM (2018) The roles of primary cilia in cardiovascular diseases. Cells. https://doi. org/10.3390/cells7120233

256. Eisa-Beygi $\mathrm{S}$ et al (2018) Characterization of endothelial cilia distribution during cerebral-vascular development in zebrafish
(Danio rerio). Arterioscler Thromb Vasc Biol 38(12):2806-2818. https://doi.org/10.1161/ATVBAHA.118.311231

257. Vion A-C et al (2018) Primary cilia sensitize endothelial cells to BMP and prevent excessive vascular regression. J Cell Biol 217(5):1651-1665. https://doi.org/10.1083/jcb.201706151

258. Liu $\mathrm{Z}$ et al (2019) Primary cilia regulate hematopoietic stem and progenitor cell specification through Notch signaling in zebrafish. Nat Commun 10(1):1839. https://doi.org/10.1038/s41467-01909403-7

259. Olstad EW et al (2019) Ciliary beating compartmentalizes cerebrospinal fluid flow in the brain and regulates ventricular development. Curr Biol 29(2):229-241.e6. https://doi.org/10.1016/j. cub.2018.11.059

260. Banizs B et al (2005) Dysfunctional cilia lead to altered ependyma and choroid plexus function, and result in the formation of hydrocephalus. Development 132(23):5329-5339. https://doi. org/10.1242/dev.02153

261. Mirzadeh Z, Han Y-G, Soriano-Navarro M, García-Verdugo JM, Alvarez-Buylla A (2010) Cilia organize ependymal planar polarity. J Neurosci 30(7):2600-2610. https://doi.org/10.1523/JNEUR OSCI.3744-09.2010

262. Sawamoto K et al (2006) New neurons follow the flow of cerebrospinal fluid in the adult brain. Science 311(5761):629-632. https://doi.org/10.1126/science.1119133

263. Kallakuri S et al (2015) Endothelial cilia are essential for developmental vascular integrity in zebrafish. JASN 26(4):864-875. https://doi.org/10.1681/ASN.2013121314

264. Ben J, Elworthy S, Ng ASM, van Eeden F, Ingham PW (2011) Targeted mutation of the talpid 3 gene in zebrafish reveals its conserved requirement for ciliogenesis and Hedgehog signalling across the vertebrates. Development 138(22):4969-4978. https ://doi.org/10.1242/dev.070862

265. Chen X, Gays D, Milia C, Santoro MM (2017) Cilia control vascular mural cell recruitment in vertebrates. Cell Rep 18(4):10331047. https://doi.org/10.1016/j.celrep.2016.12.044

266. Elworthy S, Savage AM, Wilkinson RN, Malicki JJ, Chico TJA (2019) The role of endothelial cilia in postembryonic vascular development. Dev Dyn 248(6):410-425. https://doi.org/10.1002/ dvdy. 40

267. Armulik A, Abramsson A, Betsholtz C (2005) Endothelial/ pericyte interactions. Circ Res 97(6):512-523. https://doi. org/10.1161/01.RES.0000182903.16652.d7

268. Stratman AN et al (2017) Interactions between mural cells and endothelial cells stabilize the developing zebrafish dorsal aorta. Development 144(1):115-127. https://doi.org/10.1242/ dev.143131

269. Ando $\mathrm{K}$ et al (2016) Clarification of mural cell coverage of vascular endothelial cells by live imaging of zebrafish. Development 143(8):1328-1339. https://doi.org/10.1242/dev.13265 4

270. Corliss BA, Azimi MS, Munson J, Peirce SM, Murfee WL (2016) Macrophages: an inflammatory link between angiogenesis and lymphangiogenesis. Microcirculation 23(2):95-121. https://doi.org/10.1111/micc.12259

271. Shankman LS et al (2015) KLF4-dependent phenotypic modulation of smooth muscle cells has a key role in atherosclerotic plaque pathogenesis. Nat Med 21(6):628-637. https://doi. org/10.1038/nm.3866

272. Swirski FK, Nahrendorf M (2014) Do vascular smooth muscle cells differentiate to macrophages in atherosclerotic lesions? Circ Res 115(7):605-606. https://doi.org/10.1161/CIRCR ESAHA.114.304925

273. Yamamoto $\mathrm{S}$ et al (2017) A subset of cerebrovascular pericytes originates from mature macrophages in the very early phase of vascular development in CNS. Sci Rep 7(1):1-16. https://doi. org/10.1038/s41598-017-03994-1 
274. Jung B, Arnold TD, Raschperger E, Gaengel K, Betsholtz C (2018) Visualization of vascular mural cells in developing brain using genetically labeled transgenic reporter mice. J Cereb Blood Flow Metab 38(3):456-468. https://doi. org/10.1177/0271678X17697720

275. Berthiaume A-A et al (2018) Dynamic remodeling of pericytes in vivo maintains capillary coverage in the adult mouse brain. Cell Reports 22(1):8-16. https://doi.org/10.1016/j.celre p.2017.12.016

276. Obermeier B, Daneman R, Ransohoff RM (2013) Development, maintenance and disruption of the blood-brain barrier. Nat Med 19(12):1584-1596. https://doi.org/10.1038/nm.3407

277. Villaseñor R et al (2016) Trafficking of endogenous immunoglobulins by endothelial cells at the blood-brain barrier. Sci Rep 6:25658. https://doi.org/10.1038/srep25658

278. Ma S, Kwon HJ, Johng H, Zang K, Huang Z (2013) Radial glial neural progenitors regulate nascent brain vascular network stabilization via inhibition of wnt signaling. PLoS Biol 11(1):e1001469. https://doi.org/10.1371/journal.pbio.1001469

279. Siqueira M, Francis D, Gisbert D, Gomes FCA, Stipursky J (2018) Radial glia cells control angiogenesis in the developing cerebral cortex through TGF- $\beta 1$ signaling. Mol Neurobiol 55(5):3660-3675. https://doi.org/10.1007/s12035-017-0557-8

280. Allen NJ, Lyons DA (2018) Glia as architects of central nervous system formation and function. Science 362(6411):181185. https://doi.org/10.1126/science.aat0473

281. da Silva SM, Campos GD, Gomes FCA, Stipursky J (2019) Radial glia-endothelial cells' bidirectional interactions control vascular maturation and astrocyte differentiation: impact for blood-brain barrier formation. Curr Neurovasc Res 16(4):291300. https://doi.org/10.2174/1567202616666191014120156

282. Gemberling M, Bailey TJ, Hyde DR, Poss KD (2013) The zebrafish as a model for complex tissue regeneration. Trends Genet 29(11):611-620. https://doi.org/10.1016/j. tig.2013.07.003

283. Goldman D (2014) Müller glial cell reprogramming and retina regeneration. Nat Rev Neurosci 15(7):431-442. https://doi. org/10.1038/nrn3723

284. Jurisch-Yaksi N, Yaksi E, Kizil C (2020) Radial glia in the zebrafish brain: functional, structural, and physiological comparison with the mammalian glia. Glia 68(12):2451-2470. https://doi.org/10.1002/glia.23849

285. Abbott NJ (2002) Astrocyte-endothelial interactions and bloodbrain barrier permeability. J Anat 200(6):629-638. https://doi. org/10.1046/j.1469-7580.2002.00064.x

286. Abbott NJ, Rönnbäck L, Hansson E (2006) Astrocyte-endothelial interactions at the blood-brain barrier. Nat Rev Neurosci 7(1):4153. https://doi.org/10.1038/nrn1824

287. Howarth C (2014) The contribution of astrocytes to the regulation of cerebral blood flow. Front Neurosci 8:103. https://doi. org/10.3389/fnins.2014.00103

288. Howarth $\mathrm{C}$ et al (2017) A critical role for astrocytes in hypercapnic vasodilation in brain. J Neurosci 37(9):2403-2414. https:// doi.org/10.1523/JNEUROSCI.0005-16.2016

289. Kimelberg HK (2004) The problem of astrocyte identity. Neurochem Int 45(2-3):191-202. https://doi.org/10.1016/j.neuin t.2003.08.015

290. Kimelberg HK (2010) Functions of mature mammalian astrocytes: a current view. Neuroscientist 16(1):79-106. https://doi. org/10.1177/1073858409342593

291. Kimelberg HK, Nedergaard M (2010) Functions of astrocytes and their potential as therapeutic targets. Neurotherapeutics 7(4):338-353. https://doi.org/10.1016/j.nurt.2010.07.006

292. Mathiisen TM, Lehre KP, Danbolt NC, Ottersen OP (2010) The perivascular astroglial sheath provides a complete covering of the brain microvessels: an electron microscopic 3D reconstruction. Glia 58(9):1094-1103. https://doi.org/10.1002/glia.20990

293. Keaney J, Campbell M (2015) The dynamic blood-brain barrier. FEBS J 282(21):4067-4079. https://doi.org/10.1111/febs.13412

294. Price BR, Norris CM, Sompol P, Wilcock DM (2018) An emerging role of astrocytes in vascular contributions to cognitive impairment and dementia. J Neurochem 144(5):644-650. https ://doi.org/10.1111/jnc. 14273

295. Simard M, Nedergaard M (2004) The neurobiology of glia in the context of water and ion homeostasis. Neuroscience 129(4):877896. https://doi.org/10.1016/j.neuroscience.2004.09.053

296. Bozoyan L, Khlghatyan J, Saghatelyan A (2012) Astrocytes control the development of the migration-promoting vasculature scaffold in the postnatal brain via VEGF signaling. J Neurosci 32(5):1687-1704. https://doi.org/10.1523/JNEUR OSCI.5531-11.2012

297. Duan L-J, Pan SJ, Sato TN, Fong G-H (2017) Retinal angiogenesis regulates astrocytic differentiation in neonatal mouse retinas by oxygen dependent mechanisms. Sci Rep 7(1):17608. https:// doi.org/10.1038/s41598-017-17962-2

298. Aras S, Zaidi MR (2017) TAMeless traitors: macrophages in cancer progression and metastasis. Br J Cancer 117(11):1583-1591. https://doi.org/10.1038/bjc.2017.356

299. Chanmee T, Ontong P, Konno K, Itano N (2014) Tumor-associated macrophages as major players in the tumor microenvironment. Cancers (Basel) 6(3):1670-1690. https://doi.org/10.3390/ cancers6031670

300. Bowman RL et al (2016) Macrophage ontogeny underlies differences in tumor-specific education in brain malignancies. Cell Rep 17(9):2445-2459. https://doi.org/10.1016/j.celrep.2016.10.052

301. De Palma M (2016) Origins of brain tumor macrophages. Cancer Cell 30(6):832-833. https://doi.org/10.1016/j.ccell.2016.11.015

302. Lahmar Q, Keirsse J, Laoui D, Movahedi K, Van Overmeire E, Van Ginderachter JA (2016) Tissue-resident versus monocytederived macrophages in the tumor microenvironment. Biochimica et Biophysica Acta Rev Cancer 1865(1):23-34. https://doi. org/10.1016/j.bbcan.2015.06.009

303. Prinz M, Priller J, Sisodia SS, Ransohoff RM (2011) Heterogeneity of CNS myeloid cells and their roles in neurodegeneration. Nat Neurosci 14(10):1227-1235. https://doi.org/10.1038/nn.2923

304. Lok J, Leung W, Murphy S, Butler W, Noviski N, Lo EH (2011) Intracranial hemorrhage: mechanisms of secondary brain injury. Acta Neurochir Suppl 111:63-69. https://doi. org/10.1007/978-3-7091-0693-8_11

305. Veltkamp R, Gill D (2016) Clinical trials of immunomodulation in ischemic stroke. Neurotherapeutics 13(4):791-800. https://doi. org/10.1007/s13311-016-0458-y

306. Butler MG, Gore AV, Weinstein BM (2011) Chapter 6-zebrafish as a model for hemorrhagic stroke. In: Detrich HW, Westerfield M, Zon LI (eds) Methods in cell biology, vol 105. Academic Press, Cambridge, pp 137-161

307. Crilly $\mathrm{S}$ et al (2018) Using zebrafish larval models to study brain injury, locomotor and neuroinflammatory outcomes following intracerebral haemorrhage. F1000Res. https://doi.org/10.12688 /f1000research.16473.2

308. Yu X, Li YV (2016) Zebrafish (Danio rerio) developed as an alternative animal model for focal ischemic stroke. Acta Neurochir Suppl 121:115-119. https://doi.org/10.1007/978-3-31918497-5_20

309. Wake H, Moorhouse AJ, Jinno S, Kohsaka S, Nabekura J (2009) Resting microglia directly monitor the functional state of synapses in vivo and determine the fate of ischemic terminals. J Neurosci 29(13):3974-3980. https://doi.org/10.1523/JNEUR OSCI.4363-08.2009 
310. Li Y, Du X, Liu C, Wen Z, Du J (2012) Reciprocal regulation between resting microglial dynamics and neuronal activity in vivo. Dev Cell 23(6):1189-1202. https://doi.org/10.1016/j. devcel.2012.10.027

311. Fantin A et al (2010) Tissue macrophages act as cellular chaperones for vascular anastomosis downstream of VEGF-mediated endothelial tip cell induction. Blood 116(5):829-840. https://doi. org/10.1182/blood-2009-12-257832

312. Zhang Y, Xu B, Chen Q, Yan Y, Du J, Du X (2018) Apoptosis of endothelial cells contributes to brain vessel pruning of zebrafish during development. Front Mol Neurosci. https://doi. org/10.3389/fnmol.2018.00222

313. Liu C et al (2016) Macrophages mediate the repair of brain vascular rupture through direct physical adhesion and mechanical traction. Immunity 44(5):1162-1176. https://doi.org/10.1016/j. immuni.2016.03.008

314. Gray C, Loynes CA, Whyte MKB, Crossman DC, Renshaw SA, Chico TJA (2011) Simultaneous intravital imaging of macrophage and neutrophil behaviour during inflammation using a novel transgenic zebrafish. Thromb Haemost 105(5):811-819. https://doi.org/10.1160/TH10-08-0525

315. Piccard H, Muschel RJ, Opdenakker G (2012) On the dual roles and polarized phenotypes of neutrophils in tumor development and progression. Crit Rev Oncol Hematol 82(3):296-309. https ://doi.org/10.1016/j.critrevonc.2011.06.004

316. Powell DR, Huttenlocher A (2016) Neutrophils in the tumor microenvironment. Trends Immunol 37(1):41-52. https://doi. org/10.1016/j.it.2015.11.008

317. Hao Q et al (2007) Neutrophil depletion decreases VEGFinduced focal angiogenesis in the mature mouse brain. J Cereb Blood Flow Metab 27(11):1853-1860. https://doi.org/10.1038/ sj.jcbfm. 9600485

318. Nozawa H, Chiu C, Hanahan D (2006) Infiltrating neutrophils mediate the initial angiogenic switch in a mouse model of multistage carcinogenesis. PNAS 103(33):12493-12498. https://doi. org/10.1073/pnas.0601807103

319. He S et al (2012) Neutrophil-mediated experimental metastasis is enhanced by VEGFR inhibition in a zebrafish xenograft model. J Pathol 227(4):431-445. https://doi.org/10.1002/path.4013

320. Guyader DL et al (2008) Origins and unconventional behavior of neutrophils in developing zebrafish. Blood 111(1):132-141. https://doi.org/10.1182/blood-2007-06-095398

321. Adams RH, Eichmann A (2010) Axon guidance molecules in vascular patterning. Cold Spring Harb Perspect Biol. https://doi. org/10.1101/cshperspect.a001875

322. Andreone BJ, Lacoste B, Gu C (2015) Neuronal and vascular interactions. Annu Rev Neurosci 38(1):25-46. https://doi. org/10.1146/annurev-neuro-071714-033835

323. Carmeliet $P$, Tessier-Lavigne $M$ (2005) Common mechanisms of nerve and blood vessel wiring. Nature 436(7048):193-200. https ://doi.org/10.1038/nature03875

324. Bates D et al (2003) Neurovascular congruence results from a shared patterning mechanism that utilizes Semaphorin3A and Neuropilin-1. Dev Biol 255(1):77-98. https://doi.org/10.1016/ S0012-1606(02)00045-3

325. Stubbs D et al (2009) Neurovascular congruence during cerebral cortical development. Cereb Cortex 19(Suppl 1):i32-i41. https:// doi.org/10.1093/cercor/bhp040

326. Eichmann A, Thomas J-L (2013) Molecular parallels between neural and vascular development. Cold Spring Harb Perspect Med 3(1):a006551. https://doi.org/10.1101/cshperspect.a006551

327. Wu K-W et al (2017) Neurovascular interaction promotes the morphological and functional maturation of cortical neurons. Front Cell Neurosci. https://doi.org/10.3389/fncel.2017.00290

328. Oh W-J, Gu C (2013) Establishment of neurovascular congruency in complex tissue by a novel independent patterning mechanism. Neuron 80(2):458-469. https://doi.org/10.1016/j. neuron.2013.09.005

329. Himmels $P$ et al (2017) Motor neurons control blood vessel patterning in the developing spinal cord. Nat Commun 8(1):1-16. https://doi.org/10.1038/ncomms14583

330. Karakatsani A, Shah B, Ruiz de Almodovar C (2019) Blood vessels as regulators of neural stem cell properties. Front Mol Neurosci. https://doi.org/10.3389/fnmol.2019.00085

331. Ulrich F, Ma L-H, Baker RG, Torres-Vázquez J (2011) Neurovascular development in the embryonic zebrafish hindbrain. Dev Biol 357(1):134-151. https://doi.org/10.1016/j.ydbio 2011.06.037

332. Taberner L, Bañón A, Alsina B (2018) Anatomical map of the cranial vasculature and sensory ganglia. J Anat 232(3):431-439. https://doi.org/10.1111/joa.12762

333. Gutnick A et al (2011) The hypothalamic neuropeptide oxytocin is required for formation of the neurovascular interface of the pituitary. Dev Cell 21(4):642-654. https://doi.org/10.1016/j. devcel.2011.09.004

334. Lim AH, Suli A, Yaniv K, Weinstein B, Li DY, Chien C-B (2011) Motoneurons are essential for vascular pathfinding. Development 138(21):4813. https://doi.org/10.1242/dev.075044

335. Chen BR, Kozberg MG, Bouchard MB, Shaik MA, Hillman EMC (2014) A critical role for the vascular endothelium in functional neurovascular coupling in the brain. J Am Heart Assoc. https://doi.org/10.1161/JAHA.114.000787

336. Phillips AA, Chan FH, Zheng MMZ, Krassioukov AV, Ainslie PN (2016) Neurovascular coupling in humans: physiology, methodological advances and clinical implications. J Cereb Blood Flow Metab 36(4):647-664. https://doi.org/10.1177/02716 $78 \times 15617954$

337. Stobart JLL, Lu L, Anderson HDI, Mori H, Anderson CM (2013) Astrocyte-induced cortical vasodilation is mediated by D-serine and endothelial nitric oxide synthase. PNAS 110(8):3149-3154. https://doi.org/10.1073/pnas.1215929110

338. Balbi $\mathrm{M}$ et al (2015) Dysfunction of mouse cerebral arteries during early aging. J Cereb Blood Flow Metab 35(9):1445-1453. https://doi.org/10.1038/jcbfm.2015.107

339. Duncombe J, Lennen RJ, Jansen MA, Marshall I, Wardlaw JM, Horsburgh K (2017) Ageing causes prominent neurovascular dysfunction associated with loss of astrocytic contacts and gliosis. Neuropathol Appl Neurobiol 43(6):477-491. https://doi. org/10.1111/nan.12375

340. Fabiani $\mathrm{M}$ et al (2014) Neurovascular coupling in normal aging: a combined optical, ERP and fMRI study. Neuroimage $85(\mathrm{Pt}$ 1):592-607. https://doi.org/10.1016/j.neuroimage.2013.04.113

341. Park L, Anrather J, Girouard H, Zhou P, Iadecola C (2007) Nox2derived reactive oxygen species mediate neurovascular dysregulation in the aging mouse brain. J Cereb Blood Flow Metab 27(12):1908-1918. https://doi.org/10.1038/sj.jcbfm.9600491

342. Rancillac A, Geoffroy H, Rossier J (2012) Impaired neurovascular coupling in the APPxPS1 mouse model of Alzheimer's disease. Curr Alzheimer Res 9(10):1221-1230

343. Takano T, Han X, Deane R, Zlokovic B, Nedergaard M (2007) Two-photon imaging of astrocytic $\mathrm{Ca} 2+$ signaling and the microvasculature in experimental mice models of Alzheimer's disease. Ann N Y Acad Sci 1097(1):40-50. https://doi.org/10.1196/annal s.1379.004

344. Tarantini $\mathrm{S}$ et al (2017) Demonstration of impaired neurovascular coupling responses in TG2576 mouse model of Alzheimer's disease using functional laser speckle contrast imaging. Geroscience 39(4):465-473. https://doi.org/10.1007/s11357-017-9980-z

345. Zlokovic BV (2005) Neurovascular mechanisms of Alzheimer's neurodegeneration. Trends Neurosci 28(4):202-208. https://doi. org/10.1016/j.tins.2005.02.001 
346. Kozberg M, Hillman E (2016) Neurovascular coupling and energy metabolism in the developing brain. Prog Brain Res 225:213-242. https://doi.org/10.1016/bs.pbr.2016.02.002

347. Kozberg MG, Hillman EMC (2016) Neurovascular coupling develops alongside neural circuits in the postnatal brain. Neurogenesis 3(1):e1244439. https://doi.org/10.1080/23262 133.2016.1244439

348. Colonnese MT, Phillips MA, Constantine-Paton M, Kaila K, Jasanoff A (2008) Development of hemodynamic responses and functional connectivity in rat somatosensory cortex. Nat Neurosci 11(1):72-79. https://doi.org/10.1038/nn2017

349. Kozberg MG, Chen BR, DeLeo SE, Bouchard MB, Hillman EMC (2013) Resolving the transition from negative to positive blood oxygen level-dependent responses in the developing brain. PNAS 110(11):4380-4385. https://doi.org/10.1073/pnas.12127 85110

350. Chhabria K et al (2018) The effect of hyperglycemia on neurovascular coupling and cerebrovascular patterning in zebrafish. J Cereb Blood Flow Metab. https://doi.org/10.1177/0271678X18 810615

351. Chhabria K et al (2019) Sodium nitroprusside prevents the detrimental effects of glucose on the neurovascular unit and behaviour in zebrafish. Dis Models Mech. https://doi.org/10.1242/ dmm.039867

352. Jayadev R, Sherwood DR (2017) Basement membranes. Curr Biol 27(6):R207-R211. https://doi.org/10.1016/j. cub.2017.02.006

353. Marchand M, Monnot C, Muller L, Germain S (2019) Extracellular matrix scaffolding in angiogenesis and capillary homeostasis. Semin Cell Dev Biol 89:147-156. https://doi.org/10.1016/j. semcdb.2018.08.007

354. Seano G, Primo L (2015) Podosomes and invadopodia: tools to breach vascular basement membrane. Cell Cycle 14(9):1370 1374. https://doi.org/10.1080/15384101.2015.1026523

355. Pozzi A, Yurchenco PD, Iozzo RV (2017) The nature and biology of basement membranes. Matrix Biol 57-58:1-11. https://doi. org/10.1016/j.matbio.2016.12.009

356. Thomsen MS, Routhe LJ, Moos T (2017) The vascular basement membrane in the healthy and pathological brain. J Cereb Blood Flow Metab 37(10):3300-3317. https://doi.org/10.1177/02716 $78 \times 17722436$

357. Randles MJ, Humphries MJ, Lennon R (2017) Proteomic definitions of basement membrane composition in health and disease. Matrix Biol 57-58:12-28. https://doi.org/10.1016/j.matbi o.2016.08.006

358. Hallmann R, Horn N, Selg M, Wendler O, Pausch F, Sorokin LM (2005) Expression and function of laminins in the embryonic and mature vasculature. Physiol Rev 85(3):979-1000. https:// doi.org/10.1152/physrev.00014.2004

359. Sixt M, Engelhardt B, Pausch F, Hallmann R, Wendler O, Sorokin LM (2001) Endothelial cell laminin isoforms, laminins 8 and 10, play decisive roles in $\mathrm{T}$ cell recruitment across the bloodbrain barrier in experimental autoimmune encephalomyelitis. $\mathrm{J}$ Cell Biol 153(5):933-946. https://doi.org/10.1083/jcb.153.5.933

360. Yousif LF, Di Russo J, Sorokin L (2013) Laminin isoforms in endothelial and perivascular basement membranes. Cell Adh Migr 7(1):101-110. https://doi.org/10.4161/cam.22680

361. Lee J, Gross JM (2007) Laminin beta1 and gamma1 containing laminins are essential for basement membrane integrity in the zebrafish eye. Invest Ophthalmol Vis Sci 48(6):2483-2490. https ://doi.org/10.1167/iovs.06-1211

362. Gnanaguru G, Pinzón-Duarte GA, Bachay G, Brunken WJ (2009) Laminins are key regulators of retinal angiogenesis and vascular integrity. Invest Ophthalmol Vis Sci 50(13):2928-2928
363. Gautam J, Zhang X, Yao Y (2016) The role of pericytic laminin in blood brain barrier integrity maintenance. Sci Rep 6:36450. https://doi.org/10.1038/srep36450

364. Menezes MJ, McClenahan FK, Leiton CV, Aranmolate A, Shan $X$, Colognato H (2014) The extracellular matrix protein laminin $\alpha 2$ regulates the maturation and function of the blood-brain barrier. J Neurosci 34(46):15260-15280. https://doi.org/10.1523/ JNEUROSCI.3678-13.2014

365. Biswas S, Bachay G, Chu J, Hunter DD, Brunken WJ (2017) Laminin-Dependent Interaction between Astrocytes and Microglia: A Role in Retinal Angiogenesis. Am J Pathol 187(9):21122127. https://doi.org/10.1016/j.ajpath.2017.05.016

366. Stenzel D et al (2011) Endothelial basement membrane limits tip cell formation by inducing Dll4/Notch signalling in vivo. EMBO Rep 12(11):1135-1143. https://doi.org/10.1038/embor.2011.194

367. Estrach S et al (2011) Laminin-binding integrins induce Dll4 expression and Notch signaling in endothelial cells. Circ Res 109(2):172-182. https://doi.org/10.1161/CIRCRESAHA .111 .240622

368. Pöschl E, Schlötzer-Schrehardt U, Brachvogel B, Saito K, Ninomiya Y, Mayer U (2004) Collagen IV is essential for basement membrane stability but dispensable for initiation of its assembly during early development. Development 131(7):16191628. https://doi.org/10.1242/dev.01037

369. Gould DB et al (2005) Mutations in Col4a1 cause perinatal cerebral hemorrhage and porencephaly. Science 308(5725):11671171. https://doi.org/10.1126/science. 1109418

370. Gould DB et al (2006) Role of COL4A1 in small-vessel disease and hemorrhagic stroke. N Engl J Med 354(14):1489-1496. https ://doi.org/10.1056/NEJMoa053727

371. Takeuchi M et al (2015) Type IV collagen controls the axogenesis of cerebellar granule cells by regulating basement membrane integrity in zebrafish. PLoS Genet 11(10):e1005587. https://doi. org/10.1371/journal.pgen.1005587

372. Yurchenco PD, Schittny JC (1990) Molecular architecture of basement membranes. FASEB J 4(6):1577-1590. https://doi. org/10.1096/fasebj.4.6.2180767

373. Dong L et al (2002) Neurologic defects and selective disruption of basement membranes in mice lacking entactin-1/nidogen-1. Lab Invest 82(12): 1617-1630

374. Schymeinsky J et al (2002) Gene structure and functional analysis of the mouse nidogen-2 gene: nidogen-2 is not essential for basement membrane formation in mice. Mol Cell Biol 22(19):6820 6830. https://doi.org/10.1128/mcb.22.19.6820-6830.2002

375. Salmivirta K, Talts JF, Olsson M, Sasaki T, Timpl R, Ekblom $P$ (2002) Binding of mouse nidogen-2 to basement membrane components and cells and its expression in embryonic and adult tissues suggest complementary functions of the two nidogens. Exp Cell Res 279(2):188-201. https://doi.org/10.1006/ excr.2002.5611

376. Bader BL et al (2005) Compound genetic ablation of nidogen 1 and 2 causes basement membrane defects and perinatal lethality in mice. Mol Cell Biol 25(15):6846-6856. https://doi. org/10.1128/MCB.25.15.6846-6856.2005

377. Zhu P et al (2017) Short body length phenotype is compensated by the upregulation of nidogen family members in a deleterious nid1a mutation of zebrafish. J Genet Genomics 44(11):553-556. https://doi.org/10.1016/j.jgg.2017.09.011

378. Sarrazin S, Lamanna WC, Esko JD (2011) Heparan sulfate proteoglycans. Cold Spring Harb Perspect Biol. https://doi. org/10.1101/cshperspect.a004952

379. Lord MS, Chuang CY, Melrose J, Davies MJ, Iozzo RV, Whitelock JM (2014) The role of vascular-derived perlecan in modulating cell adhesion, proliferation and growth factor signaling. Matrix Biol 35:112-122. https://doi.org/10.1016/j.matbi o.2014.01.016 
380. Fukuda S, Fini CA, Mabuchi T, Koziol JA, Eggleston LL, del Zoppo GJ (2004) Focal cerebral ischemia induces active proteases that degrade microvascular matrix. Stroke 35(4):9981004. https://doi.org/10.1161/01.STR.0000119383.76447.05

381. Gustafsson E, Almonte-Becerril M, Bloch W, Costell M (2013) Perlecan maintains microvessel integrity in vivo and modulates their formation in vitro. PLoS ONE 8(1):e53715. https://doi. org/10.1371/journal.pone.0053715

382. Costell M, Carmona R, Gustafsson E, González-Iriarte M, Fässler R, Muñoz-Chápuli R (2002) Hyperplastic conotruncal endocardial cushions and transposition of great arteries in perlecan-null mice. Circ Res 91(2):158-164. https://doi. org/10.1161/01.res.0000026056.81424.da

383. González-Iriarte M, Carmona R, Pérez-Pomares JM, Macías D, Costell M, Muñoz-Chápuli R (2003) Development of the coronary arteries in a murine model of transposition of great arteries. J Mol Cell Cardiol 35(7):795-802. https://doi.org/10.1016/s0022 -2828(03)00134-2

384. Mongiat M, Sweeney SM, San Antonio JD, Fu J, Iozzo RV (2003) Endorepellin, a novel inhibitor of angiogenesis derived from the C terminus of perlecan. J Biol Chem. 278(6):42384249. https://doi.org/10.1074/jbc.M210445200

385. Zoeller JJ, McQuillan A, Whitelock J, Ho S-Y, Iozzo RV (2008) A central function for perlecan in skeletal muscle and cardiovascular development. J Cell Biol 181(2):381-394. https://doi. org/10.1083/jcb.200708022

386. Zoeller JJ, Whitelock JM, Iozzo RV (2009) Perlecan regulates developmental angiogenesis by modulating the VEGF-VEGFR2 axis. Matrix Biol 28(5):284-291. https://doi.org/10.1016/j.matbi o.2009.04.010

387. Kim MJ et al (2007) Agrin is required for posterior development and motor axon outgrowth and branching in embryonic zebrafish. Glycobiology 17(2):231-247. https://doi.org/10.1093/ glycob/cwl069

388. Liu I-H, Zhang C, Kim MJ, Cole GJ (2008) Retina development in zebrafish requires the heparan sulfate proteoglycan agrin. Dev Neurobiol 68(7):877-898. https://doi.org/10.1002/dneu.20625

389. Bassat $\mathrm{E}$ et al (2017) The extracellular matrix protein agrin promotes heart regeneration in mice. Nature 547(7662):179-184. https://doi.org/10.1038/nature22978

390. Steiner E et al (2014) The heparan sulfate proteoglycan agrin contributes to barrier properties of mouse brain endothelial cells by stabilizing adherens junctions. Cell Tissue Res 358(2):465479. https://doi.org/10.1007/s00441-014-1969-7

391. Barber AJ, Lieth E (1997) Agrin accumulates in the brain microvascular basal lamina during development of the blood-brain barrier. Dev Dyn 208(1):6274. https://doi.org/10.1002/(SICI)1097-0177(19970 1)208:1\%3c62::AID-AJA6\%3e3.0.CO;2-\#

392. van Hinsbergh VWM, Koolwijk P (2008) Endothelial sprouting and angiogenesis: matrix metalloproteinases in the lead. Cardiovasc Res 78(2):203-212. https://doi.org/10.1093/cvr/ cvm 102

393. Jabłońska-Trypuć A, Matejczyk M, Rosochacki S (2016) Matrix metalloproteinases (MMPs), the main extracellular matrix (ECM) enzymes in collagen degradation, as a target for anticancer drugs. J Enzyme Inhib Med Chem 31(sup1):177183. https://doi.org/10.3109/14756366.2016.1161620

394. Stetler-Stevenson WG (1999) Matrix metalloproteinases in angiogenesis: a moving target for therapeutic intervention. J Clin Invest 103(9):1237-1241. https://doi.org/10.1172/JCI68 70

395. Chang D-I et al (2003) Activation systems for latent matrix metalloproteinase-2 are upregulated immediately after focal cerebral ischemia. J Cereb Blood Flow Metab 23(12):14081419. https://doi.org/10.1097/01.WCB.0000091765.61714.30
396. Hosomi N, Lucero J, Heo JH, Koziol JA, Copeland BR, del Zoppo GJ (2001) Rapid differential endogenous plasminogen activator expression after acute middle cerebral artery occlusion. Stroke 32(6):1341-1348. https://doi.org/10.1161/01. str.32.6.1341

397. Kozol RA, Abrams AJ, James DM, Buglo E, Yan Q, Dallman JE (2016) Function over form: modeling groups of inherited neurological conditions in zebrafish. Front Mol Neurosci. https ://doi.org/10.3389/fnmol.2016.00055

398. Bill BR, Korzh V (2014) Choroid plexus in developmental and evolutionary perspective. Front Neurosci. https://doi. org/10.3389/fnins.2014.00363

399. Korzh V (2018) Development of brain ventricular system. Cell Mol Life Sci 75(3):375-383. https://doi.org/10.1007/s0001 8-017-2605-y

400. Kimelberg HK (2004) Water homeostasis in the brain: basic concepts. Neuroscience 129(4):851-860. https://doi. org/10.1016/j.neuroscience.2004.07.033

401. Lun MP, Monuki ES, Lehtinen MK (2015) Development and functions of the choroid plexus-cerebrospinal fluid system. Nat Rev Neurosci 16(8):445-457. https://doi.org/10.1038/nrn3921

402. Orešković D, Klarica M (2010) The formation of cerebrospinal fluid: Nearly a hundred years of interpretations and misinterpretations. Brain Res Rev 64(2):241-262. https://doi. org/10.1016/j.brainresrev.2010.04.006

403. Orešković D, Klarica M (2014) A new look at cerebrospinal fluid movement. Fluids Barriers CNS 11:16. https://doi. org/10.1186/2045-8118-11-16

404. Klose U, Strik C, Kiefer C, Grodd W (2000) Detection of a relation between respiration and CSF pulsation with an echoplanar technique. J Magn Reson Imaging 11(4):438-444. https ://doi.org/10.1002/(sici)1522-2586(200004)11:4\%3c438::aidjmri12\%3e3.0.co;2-o

405. Yamada $\mathrm{S}$ et al (2013) Influence of respiration on cerebrospinal fluid movement using magnetic resonance spin labeling. Fluids Barriers CNS 10(1):36. https://doi. org/10.1186/2045-8118-10-36

406. Xu Q et al (2016) Head movement, an important contributor to human cerebrospinal fluid circulation. Scientific Reports 6:31787. https://doi.org/10.1038/srep31787

407. Faubel R, Westendorf C, Bodenschatz E, Eichele G (2016) Cilia-based flow network in the brain ventricles. Science 353(6295):176-178. https://doi.org/10.1126/science.aae0450

408. Ibañez-Tallon I et al (2004) Dysfunction of axonemal dynein heavy chain Mdnah5 inhibits ependymal flow and reveals a novel mechanism for hydrocephalus formation. Hum Mol Genet 13(18):2133-2141. https://doi.org/10.1093/hmg/ddh219

409. Ballabh P, Braun A, Nedergaard M (2004) The blood-brain barrier: an overview: structure, regulation, and clinical implications. Neurobiol Dis 16(1):1-13. https://doi.org/10.1016/j. nbd.2003.12.016

410. Munji RN et al (2019) Profiling the mouse brain endothelial transcriptome in health and disease models reveals a core bloodbrain barrier dysfunction module. Nat Neurosci 22(11):18921902. https://doi.org/10.1038/s41593-019-0497-x

411. Eliceiri BP, Gonzalez AM, Baird A (2011) Zebrafish model of the blood-brain barrier: morphological and permeability studies. Methods Mol Biol 686:371-378. https://doi.org/10.1007/978-160761-938-3_18

412. Fleming A, Diekmann H, Goldsmith P (2013) Functional characterisation of the maturation of the blood-brain barrier in larval zebrafish. PLoS ONE 8(10):e77548. https://doi.org/10.1371/ journal.pone.0077548

413. van Leeuwen $L$ et al (2017) A transgenic zebrafish model for the in vivo study of the blood and choroid plexus brain barriers using claudin 5. bioRxiv. https://doi.org/10.1101/180653 
414. Quiñonez-Silvero C, Hübner K, Herzog W (2019) Development of the brain vasculature and the blood-brain barrier in zebrafish. Dev Biol. https://doi.org/10.1016/j.ydbio.2019.03.005

415. Xie J, Farage E, Sugimoto M, Anand-Apte B (2010) A novel transgenic zebrafish model for blood-brain and blood-retinal barrier development. BMC Dev Biol 10:76. https://doi. org/10.1186/1471-213X-10-76

416. Umans RA et al (2017) CNS angiogenesis and barriergenesis occur simultaneously. Dev Biol 425(2):101-108. https://doi. org/10.1016/j.ydbio.2017.03.017

417. Aspelund A et al (2015) A dural lymphatic vascular system that drains brain interstitial fluid and macromolecules. J Exp Med 212(7):991-999. https://doi.org/10.1084/jem.20142290

418. Louveau A et al (2015) Structural and functional features of central nervous system lymphatic vessels. Nature 523(7560):337341. https://doi.org/10.1038/nature14432

419. Bower NI et al (2017) Mural lymphatic endothelial cells regulate meningeal angiogenesis in the zebrafish. Nat Neurosci 20(6):774-783. https://doi.org/10.1038/nn.4558

420. Galanternik MV et al (2017) A novel perivascular cell population in the zebrafish brain. eLife 6:e24369. https://doi.org/10.7554/ eLife. 24369

421. van Lessen M, Shibata-Germanos S, van Impel A, Hawkins TA, Rihel J, Schulte-Merker S (2017) Intracellular uptake of macromolecules by brain lymphatic endothelial cells during zebrafish embryonic development. eLife 6:e25932. https://doi.org/10.7554/ eLife. 25932

422. Absinta $\mathrm{M}$ et al (2017) Human and nonhuman primate meninges harbor lymphatic vessels that can be visualized noninvasively by MRI. Elife 6:03. https://doi.org/10.7554/eLife.29738

423. Bower NI, Hogan BM (2018) Brain drains: new insights into brain clearance pathways from lymphatic biology. J Mol Med 96(5):383-390. https://doi.org/10.1007/s00109-018-1634-9

424. Chen J, He J, Ni R, Yang Q, Zhang Y, Luo L (2019) Cerebrovascular injuries induce lymphatic invasion into brain parenchyma to guide vascular regeneration in zebrafish. Dev Cell 49(5):697710.e5. https://doi.org/10.1016/j.devcel.2019.03.022

425. Iliff JJ et al (2012) A paravascular pathway facilitates CSF flow through the brain parenchyma and the clearance of interstitial solutes, including amyloid $\beta$. Sci Transl Med 4(147):147111. https://doi.org/10.1126/scitranslmed.3003748

426. Xie L et al (2013) Sleep drives metabolite clearance from the adult brain. Science 342(6156):373-377. https://doi.org/10.1126/ science. 1241224

427. Benveniste H, Liu X, Koundal S, Sanggaard S, Lee H, Wardlaw J (2019) The glymphatic system and waste clearance with brain aging: a review. GER 65(2):106-119. https://doi. org/10.1159/000490349

428. Jessen NA, Munk ASF, Lundgaard I, Nedergaard M (2015) The glymphatic system: a beginner's guide. Neurochem Res 40(12):2583-2599. https://doi.org/10.1007/s11064-015-1581-6

429. Plog BA, Nedergaard M (2018) The glymphatic system in central nervous system health and disease: past, present, and future. Annu Rev Pathol 13:379-394. https://doi.org/10.1146/annurevpathol-051217-111018

430. Semyachkina-Glushkovskaya O, Postnov D, Kurths J (2018) Blood-brain barrier, lymphatic clearance, and recovery: Ariadne's thread in labyrinths of hypotheses. Int J Mol Sci. https:// doi.org/10.3390/ijms19123818

431. Baldessari D, Mione M (2008) How to create the vascular tree? (Latest) help from the zebrafish. Pharmacol Ther 118(2):206230. https://doi.org/10.1016/j.pharmthera.2008.02.010

432. Hogan BM, Schulte-Merker S (2017) How to plumb a pisces: understanding vascular development and disease using zebrafish embryos. Dev Cell 42(6):567-583. https://doi.org/10.1016/j. devcel.2017.08.015
433. Kume T (2010) Specification of arterial, venous, and lymphatic endothelial cells during embryonic development. Histol Histopathol 25(5):637-646. https://doi.org/10.14670/HH-25.637

434. Takeshita Y, Obermeier B, Cotleur A, Sano Y, Kanda T, Ransohoff RM (2014) An in vitro blood-brain barrier model combining shear stress and endothelial cell/astrocyte co-culture. J Neurosci Methods 232:165-172. https://doi.org/10.1016/j.jneum eth.2014.05.013

435. Adriani G, Ma D, Pavesi A, Goh ELK, Kamm RD (2015) Modeling the blood-brain barrier in a 3D triple co-culture microfluidic system. In: 2015 37th annual international conference of the IEEE engineering in medicine and biology society (EMBC), pp 338-341. doi: https://doi.org/10.1109/EMBC.2015.7318368.

436. Quadrato $\mathrm{G}$ et al (2017) Cell diversity and network dynamics in photosensitive human brain organoids. Nature. https://doi. org/10.1038/nature22047

437. Schutgens F, Clevers H (2020) Human organoids: tools for understanding biology and treating diseases. Annu Rev Pathol 15(1):211-234. https://doi.org/10.1146/annurev-pathmechdi s-012419-032611

438. Bassi A, Fieramonti L, D’Andrea C, Mione M, Valentini G (2011) In vivo label-free three-dimensional imaging of zebrafish vasculature with optical projection tomography. J Biomed Opt 16(10):100502. https://doi.org/10.1117/1.3640808

439. Correia $\mathrm{T}$ et al (2015) Accelerated optical projection tomography applied to in vivo imaging of zebrafish. PLoS ONE 10(8):e0136213. https://doi.org/10.1371/journal.pone.0136213

440. Kumar S et al (2016) Quantitative in vivo optical tomography of cancer progression \& vasculature development in adult zebrafish. Oncotarget 7(28):43939-43948. https://doi.org/10.18632/oncot arget.9756

441. Koth J et al (2017) High-resolution magnetic resonance imaging of the regenerating adult zebrafish heart. Sci Rep 7(1):2917. https ://doi.org/10.1038/s41598-017-03050-y

442. Merrifield GD et al (2017) Rapid and recoverable in vivo magnetic resonance imaging of the adult zebrafish at 7T. Magn Reson Imaging 37:9-15. https://doi.org/10.1016/j.mri.2016.10.013

443. Kline TL et al (2019) Three-dimensional NMR microscopy of zebrafish specimens. NMR Biomed 32(1):e4031. https://doi. org/10.1002/nbm.4031

444. Bassi A, Schmid B, Huisken J (2015) Optical tomography complements light sheet microscopy for in toto imaging of zebrafish development. Development 142(5):1016-1020. https://doi. org/10.1242/dev.116970

445. Kugler E, Plant K, Chico T, Armitage P (2019) Enhancement and segmentation workflow for the developing zebrafish vasculature. J Imaging 5(1):14. https://doi.org/10.3390/jimaging5010014

446. Gupta T, Marquart GD, Horstick EJ, Tabor KM, Pajevic S, Burgess HA (2018) Morphometric analysis and neuroanatomical mapping of the zebrafish brain. Methods 150:49-62. https://doi. org/10.1016/j.ymeth.2018.06.008

447. Marquart GD et al (2017) High-precision registration between zebrafish brain atlases using symmetric diffeomorphic normalization. Gigascience 6(8):1-15. https://doi.org/10.1093/gigas cience/gix 056

448. Randlett $\mathrm{O}$ et al (2015) Whole-brain activity mapping onto a zebrafish brain atlas. Nat Methods 12(11):1039-1046. https:// doi.org/10.1038/nmeth.3581

449. Ronneberger O et al (2012) ViBE-Z: a framework for 3D virtual colocalization analysis in zebrafish larval brains. Nat Methods 9(7):735-742. https://doi.org/10.1038/nmeth.2076

450. Cox CM, Poole TJ (2000) Angioblast differentiation is influenced by the local environment: FGF-2 induces angioblasts and patterns vessel formation in the quail embryo. Dev Dyn 218(2):371-382. https://doi.org/10.1002/(SICI)1097-0177(200006)218:2\%3c371 ::AID-DVDY10\%3e3.0.CO;2-Z 
451. Funa K, Sasahara M (2014) The roles of PDGF in development and during neurogenesis in the normal and diseased nervous system. J Neuroimmune Pharmacol 9(2):168-181. https://doi. org/10.1007/s11481-013-9479-z
Publisher's Note Springer Nature remains neutral with regard to jurisdictional claims in published maps and institutional affiliations. 